\title{
Human HPK1, a novel human hematopoietic progenitor kinase that activates the JNK/SAPK kinase cascade
}

\author{
Mickey C.-T. Hu, ${ }^{1,3}$ Wan R. Qiu, ${ }^{1}$ Xiaoping Wang, ${ }^{2}$ Christian F. Meyer, ${ }^{2}$ and Tse-Hua Tan ${ }^{2,3}$ \\ ${ }^{1}$ Department of Experimental Hematology, Amgen, Inc., Thousand Oaks, California 91320 USA; ${ }^{2}$ Department of \\ Microbiology and Immunology, Baylor College of Medicine, Houston, Texas 77030 USA
}

The c-Jun amino-terminal kinases (JNKs)/stress-activated protein kinases (SAPKs) play a crucial role in stress responses in mammalian cells. The mechanism underlying this pathway in the hematopoietic system is unclear, but it is a key in understanding the molecular basis of blood cell differentiation. We have cloned a novel protein kinase, termed hematopoietic progenitor kinase 1 (HPK1), that is expressed predominantly in

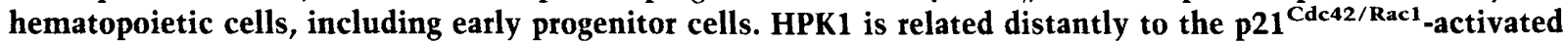
kinase (PAK) and yeast STE20 implicated in the mitogen-activated protein kinase (MAPK) cascade. Expression of HPK1 activates JNK1 specifically, and it elevates strongly AP-1-mediated transcriptional activity in vivo. HPK1 binds and phosphorylates MEKK1 directly, whereas JNK1 activation by HPK1 is inhibited by a dominant-negative MEKK1 or MKK4/SEK mutant. Interestingly, unlike PAK65, HPK1 does not contain the small GTPase Rac1/Cdc42-binding domain and does not bind to either Rac1 or Cdc42, suggesting that HPK1 activation is Rac1/Cdc42-independent. These results indicate that HPK1 is a novel functional activator of the JNK/SAPK signaling pathway.

[Key Words: JNK/SAPK; protein kinase; MAP kinase; signal transduction; hematopoietic cells]

Received June 13, 1996; revised version accepted August 5, 1996.

The mitogen-activated protein kinase (MAPK) cascade is a major signaling system by which cells transduce extracellular stimuli into intracellular signals to control the expression of genes essential for cellular processes such as cell proliferation, differentiation, and stress responses (for review, see Cobb and Goldsmith 1995; Hunter 1995). In mammalian cells, these kinases include extracellular signal-regulated protein kinases (ERKs; Davis 1993), p38MAPK (Han et al. 1994; Jiang et al. 1996), and the c-Jun amino-terminal kinases (JNKs)/stress-activated protein kinases (SAPKs) (Derijard et al. 1994; Kyriakis et al. 1994; Gupta et al. 1996). These kinases have the unique feature of being activated by phosphorylation on threonine (Thr) and tyrosine (Tyr) residues by an upstream dual specificity kinase (for review, see Davis 1994; Karin 1995). ERKs are activated rapidly in response to the binding of ligands to growth factor receptors [e.g., epidermal growth factor (EGF) receptors] that are tyrosine kinases or receptors (e.g., thrombin receptors) that are coupled to heterotrimeric guanine nucleotide-binding proteins $/ G$ proteins). The function of p38-MAPK in mammalian cells is not so clear; however, it seems to participate in the signaling pathways of proinflammatory cytokines and environmental stress, including interleukin-1 (IL-1), tumor necrosis factor $\alpha$ (TNF $\alpha)$, lipopolysaccharide

${ }^{3}$ Corresponding authors.
(LPS), and osmotic shock (Han et al. 1994; Raingeaud et al. 1995). INKs/SAPKs play a crucial role in the responses stimulated by proinflammatory cytokines, environmental stress, and apoptotic agents (Xia et al. 1995; Chen et al. 1996; Verheij et al. 1996). There are a number of extracellular stimulants that can potently activate JNKs/SAPKs, which include certain growth factors, proinflammatory cytokines (TNF $\alpha$ and IL-1), G proteincoupled receptors, lymphocyte costimulatory receptors (CD28 and CD40), ceramides, protein synthesis inhibitors, osmotic shock, heat shock, DNA-damaging chemicals, ultraviolet irradiation, and $\gamma$ irradiation (Derijard et al. 1994; Kyriakis et al. 1994; Su et al. 1994; Coso et al. 1995; Sakata et al. 1995; Saleem et al. 1995; Westwick et al. 1995; Chen et al. 1996; Verheij et al. 1996). JNKs/ SAPKs can phosphorylate the trans-activating domain of c-Jun (Derijard et al. 1994; Kyriakis et al. 1994); as a result, the phosphorylated c-Iun becomes active transcriptionally and regulates the expression of many genes including c-Jun itself (Angel et al. 1988). It has been shown that the MAPK/ERK kinase kinase 1 (MEKK1; Lange-Carter et al. 1993) specifically regulates MKK4 (also called SEK or JNKK) activity and functions preferentially in the JNK/SAPK signaling pathway (Minden et al. 1994; Yan et al. 1994; Derijard et al. 1995). However, the upstream molecules that control MEKK1 directly are yet to be identified. 
Signal transduction pathways connecting cell surface receptors with each member of the MAPK superfamily in mammalian cells are remarkably similar to those of the budding yeast Saccharomyces cerevisiae, in which genetic studies have shown parallel signaling cascades leading to the activation of at least three distinct MAPKrelated kinases (for review, see Herskowitz 1995). In the yeast pheromone signaling cascade, a Ser/Thr kinase (STE20) activates STE11 and STE7 sequentially, which in turn phosphorylates and activates the yeast MAPK homologs FUS3 and KSS1. STE7 is the yeast homolog of mammalian MEKs and MKK4/SEK/JNKK (Minden et al. 1994; Sanchez et al. 1994; Derijard et al. 1995), which phosphorylates and activates JNKs/SAPKs directly. STE11 is the yeast homolog of mammalian Raf and MEKK1 (Lange-Carter et al. 1993). Recently, it has been shown that the JNK/SAPK signaling pathway is regulated by the small GTP-binding proteins Racl and Cdc42 (Coso et al. 1995; Minden 1995), which activate a Ser/ Thr protein kinase called PAK65 (Manser et al. 1994; Martin et al. 1995). Because Racl and Cdc42 activate PAK65, a STE20 homolog, and also regulate JNKs/ SAPKs activity, it has been postulated that either PAKs or related kinases may connect Racl and $\mathrm{Cdc} 42$ to the MEKK1-MKK4/SEK/JNKK-INK/SAPK pathway. To date, the identity of the molecules that control MEKK 1 directly still remains unclear.

The control of hematopoiesis is a highly regulated process that responds to a number of physiological stimuli in the human body. Differentiation, proliferation, growth arrest, or apoptosis of blood cells depends on the presence of appropriate cytokines and their receptors, as well as the corresponding cellular signal transduction cascades. Although the JNK/SAPK signaling pathway has been characterized, the mechanism underlying this pathway in hematopoietic systems is unclear; but, it is a key in understanding the molecular basis of differentiation of blood cells. We report here the cloning and characterization of a novel human hematopoietic Ser/Thr protein kinase called hematopoietic progenitor kinase 1 (HPKl), which is a tissue-specific upstream activator of the MEKK1-JNK signaling pathway.

\section{Results}

HPK1 is a novel Ser/Thr protein kinase

A murine partial cDNA was identified from a subtracted cDNA library between a granulocyte-macrophage progenitor and an erythrocyte-megakaryocyte progenitor (N.N. Iscove, pers. comm.). Comparison of this cDNA sequence with a data base at Amgen revealed an identical expressed sequence tag (EST) sequence from a cDNA library generated from 5-fluorouracil-treated mouse bone marrow, suggesting that this cDNA is expressed in early hematopoietic progenitor cells. Using this murine cDNA as a probe, we have isolated two full-length cDNA clones from a human fetal liver cDNA library. These two cDNA clones differ at their carboxyl termini presumably attributable to alternative splicing (Fig. 1A).

The primary structure showed a $2.5-\mathrm{kb}$ open reading frame encoding a novel intracellular protein kinase with a predicted molecular mass of $\sim 90 \mathrm{kD}$ (833 amino acids), which was designated as human hematopoietic progenitor kinase 1 (hHPK1). The sequence of the amino-terminal kinase domain suggests that it should be a Ser/Thr kinase. Within the kinase domain, hHPKl displayed strong homology to the human germinal center kinase (hGCK; Katz et al. 1994), human PAK65 (Martin et al. 1995), yeast STE20 (Leberer et al. 1992; Ramer and Davis 1993), yeast SHK1 (Marcus et al. 1995), and yeast SPS1 (Friesen et al. 1994) (Fig. 1B). Thus far, the PAK family includes at least hPAKl (hPAK65) (Martin et al. 1995), hPAK2 (J. Chernoff, direct submission to GenBank, U24153, unpubl.), and mPAK3 (Bagrodia et al. 1995b). Although the kinase domain of hHPK1 shares $\sim 63 \%$ homology with that of the PAK family, hPAK1 is highly homologous to that of hPAK2 $199.6 \%$ identity), and to that of mouse PAK3 $190.7 \%$ identity; $97 \%$ homology with conservative changes) (Fig. 1C). Outside of the kinase domain, there are four proline-rich domains (the putative SH3 domain-binding sites) (Feng et al. 1994; Cohen et al. 1995) between amino acids 308-474. The remaining carboxy-terminal stretch has little homology with other known sequences in the data base. The relative positions of the catalytic domains and the distribu-

Figure 1. Primary structure of human HPKl (hHPK1) and sequence comparison. Two hHPKl cDNA clones were isolated from a human fetal liver cDNA library. These two clones differ at the carboxyl termini presumably attributable to alternative splicing. $(A$, top) The nucleotide sequence and the deduced amino acid sequence of hHPK1 (clone FL-1; GenBank accession no. 66464). The proline-rich domains (the putative SH3-domain binding sites; Feng et al. 1994; Cohen et al. 1995) are boxed and the proposed alternative splice site is indicated as an arrow. The polyadenylation site in the 3' UTR is underlined. (Bottom) A comparison between the amino acid sequence of the carboxyl termini of clones FL-1 and FL-2 (begins at residue 800$)$. $(B)$ The predicted amino acid sequence of the kinase domain for hHPKl was aligned with the corresponding domains of hGCK (Katz et al. 1994; $84 \%$ ), hPAK65 (Martin et al. 1995; 63\%), STE20 (Leberer et al. 1992; Ramer and Davis 1993; 63\%), SHK1 (Marcus et al. 1995; 62\%), and SPS1 (Friesen et al. 1994; $63 \%)$. The positions of gaps, introduced to maintain alignment and denoted by dashes, were guided by the comparisons of Hanks (1991). The identical sequences among at least four proteins are highlighted with solid boxes. Roman numerals on the top line denote the 12 conserved kinase subdomains identified by Hanks and Quinn (1991). The bottom line indicates amino acids that are invariant (uppercase) or almost invariant (lowercase) in a comparison of the catalytic domains of $100 \mathrm{Ser} / \mathrm{Thr}$ protein kinases (Hanks 1991). (C) This shows a schematic presentation of the percent amino acid sequence similarity between hHPK1 and PAK kinases. The percentage was obtained by comparing the catalytic domains of each deduced amino acid sequence. $(D)$ This schematic illustration shows the structure of hHPK1 compared with those of related kinases. The catalytic domains are shown as the shaded boxes. The proline-rich domains are indicated as solid vertical boxes. 
tion of the proline-rich domains are not conserved among these protein kinases (Fig. 1D).

Our initial interest in this cDNA was based on its preferential expression in murine hematopoietic multipotential precursor cells and its significant homology with $\mathrm{p} 21^{\mathrm{Rac} / \mathrm{Cdc} 42}$-activated kinase PAK65 and yeast STE20. Members of the PAK family in mammalian cells are activated by the GTP-bound forms of $\mathrm{Cdc} 42$ and Rac1 (Manser et al. 1994; Martin et al. 1995), which recently have been shown to play a key role in controlling

A

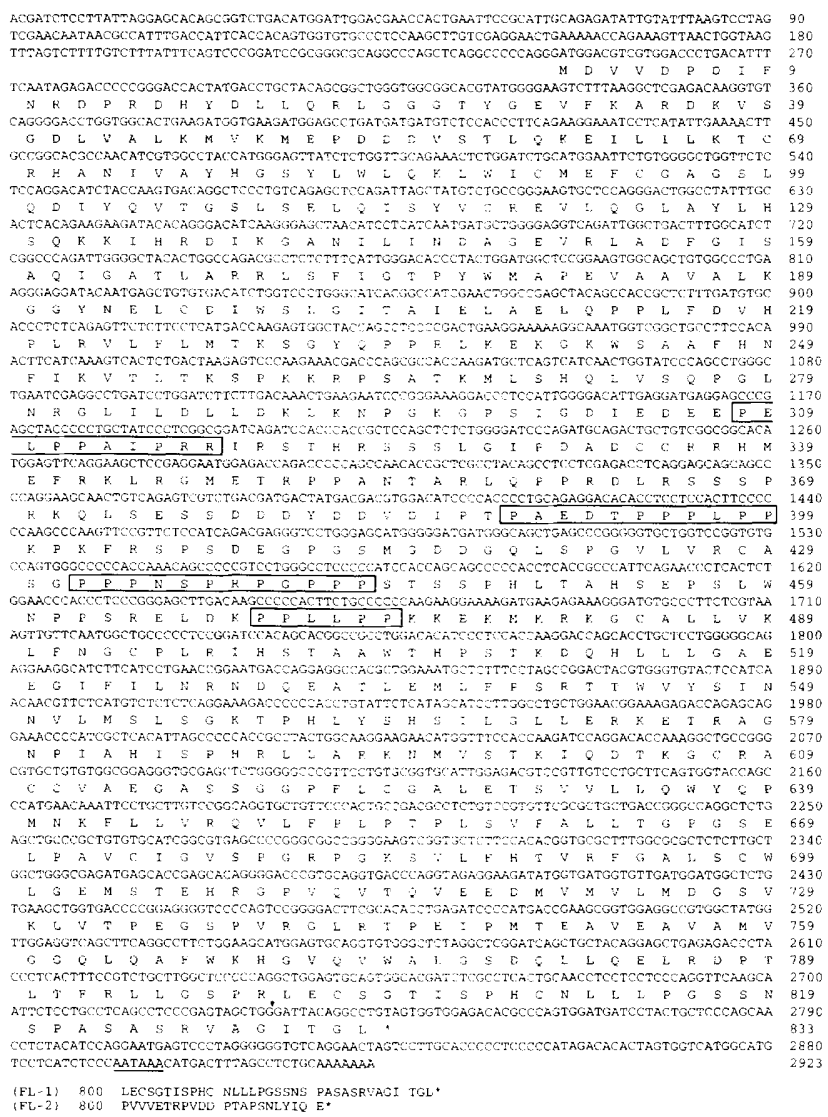

B

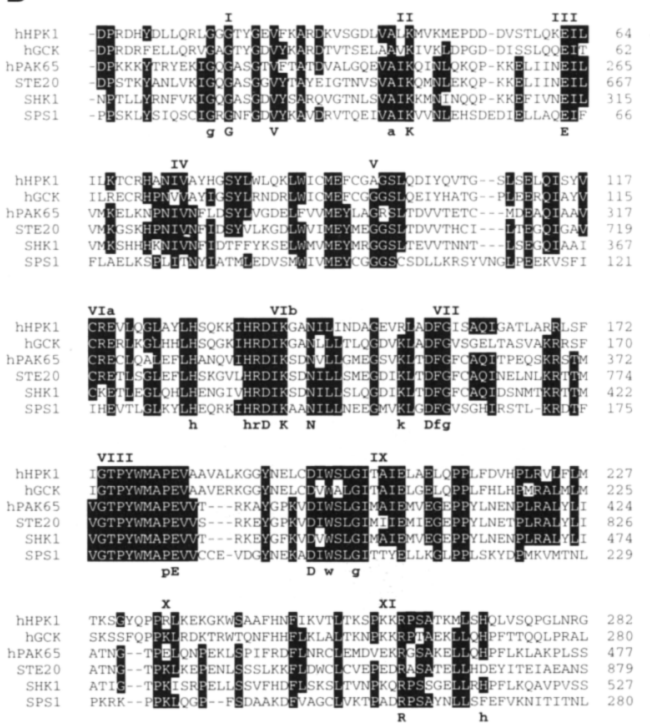

C

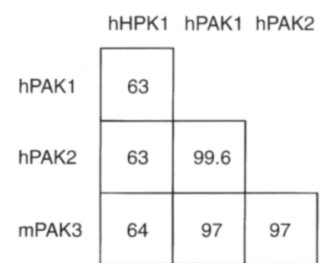

Figure 1. (See facing page for legend.) 
the activity of the JNK/SAPK signal transduction pathway (Coso et al. 1995; Minden et al. 1995). STE20 in S. cerevisiae transmits the signal elicited by the binding of pheromones to their receptor from a heterotrimeric G-protein to the STE11-STE7-FUS3/KSS1 MAPK cascade (for review, see Herskowitz 1995). The sequence similarity between HPKl and these activators of the MAPK cascades suggests that HPK1 may be involved in the activation of a MAPK pathway, perhaps the JNK/ SAPK signaling pathway. Similar to PAK and germinal center kinase (GCK), HPK1 autophosphorylated itself and phosphorylated substrates such as myelin basic protein (MBP) (Fig. 2A,B). Unlike GCK (Katz et al. 1994), however, HPK1 phosphorylated Histone IIA. As controls, the HPKl carboxy-terminal domain (amino acids 292-833), designated HPK 1-CD, and a kinase-defective HPK1 mutant [the Lys-46 in the kinase domain was substituted with Met, designated HPK1-M(46)] (see Fig. 4C) did not phosphorylate the substrate MBP (Fig. 2C), indicating that the HPK1 kinase activity observed was not attributable to coimmunoprecipitated enzymes. Furthermore, phosphoamino acid analysis of in vitro phosphorylated MBP (Fig. 2D) and autophosphorylated HPK1 (data not shown) detected P-Ser and P-Thr only, establishing HPK1 as a Ser/Thr kinase.

\section{HPK1 is expressed predominantly in hematopoietic cells}

To examine the tissue distribution of HPK l, we investigated the level of HPK1 mRNA in several human tissues and cell lines by Northern blot analysis. Two major distinct HPK1 transcripts $(2.8 \mathrm{~kb}$ and $6.0 \mathrm{~kb})$ were detected primarily in hematopoietic organs, including bone marrow, fetal liver, lymph node, placenta, spleen, thymus, and in several hematopoietic cell lines, including MOLT-4 (lymphoblastic leukemia), Daudi (Burkitt lym- phoma), Raji (Burkitt lymphoma), KGla (myelogenous leukemia), and TF-1 (factor-dependent immature erythroleukemia) (Fig. 3A). Very low levels of these two HPK1 transcripts were detected in the lung, kidney, mammary glands, and small intestine. Neither of the two transcripts was detected elsewhere including the brain, heart, liver, muscle, pancreas, prostate, testis, and thyroid. Expression of HPKl in several hematopoietic cell lines was further confirmed by immunoprecipitationWestern blot analysis (Fig. 3B). A 97-kD HPK1 protein was detected in TF-1, KGla, Raji, Daudi, and the protein levels correlated well with that of transcripts detected in Northern blot analysis. HPK 1 is also expressed in Jurkat cells (T-cell leukemia; data not shown). To test whether the cDNA encodes full-length HPKl, we transfected HPK1 cDNA into COS-7 cells for transient expression. We detected a $97-\mathrm{kD}$ protein comigrating with HPK1 expressed in hematopoietic cell lines (Fig. 3B, lane 3), indicating that the cDNA encoded the full-length coding region of HPK 1 .

To determine whether HPKl is expressed in early hematopoietic progenitor cells, we purified human $\mathrm{CD} 34^{+}$, $\mathrm{CD} 34^{-}, \mathrm{CD} 34^{+} \mathrm{CD} 38^{+}, \mathrm{CD} 34^{+} \mathrm{CD} 38^{-}, \mathrm{CD} 34^{+} \mathrm{HLA}^{-}$ $\mathrm{DR}^{+}$cells from bone marrow or fetal liver by FACScan sorting. Total RNA was purified from these cells and HPKl transcripts were detected by RT-PCR technique using two primers derived from the HPK 1 kinase domain (see Materials and Methods). As shown in Figure 3C, HPKl was expressed in all five populations, with higher levels in $\mathrm{CD} 34^{+} \mathrm{CD} 38^{-}$cells than $\mathrm{CD} 34^{+} \mathrm{CD} 38^{+}$ cells. The expression levels in $\mathrm{CD} 34^{+} \mathrm{HLA}^{-} \mathrm{DR}^{+}$and $\mathrm{CD} 34^{+} \mathrm{CD} 38^{-}$populations were approximately the same. Because the $\mathrm{CD} 34^{+} \mathrm{CD} 38^{-}$population contains more early progenitor cells and stem cells than the $\mathrm{CD} 34^{+} \mathrm{CD} 38^{+}$population (Huang and Terstapper 1994), our results suggest that HPK1 is not only expressed in more committed progenitor cells, but in early progenitor
Figure 2. Catalytic activity of human HPKl. (A) Endogenous HPK1 was immunoprecipitated from Daudi cells with either control serum or anti-HPK1 anti-serum and subjected to an immunocomplex kinase assay in the presence of the indicated substrates. (B) HPK1 was immunoprecipitated from transiently transfected COS-7 cells using anti-HPK1 antiserum and subjected to an immunocomplex kinase assay. The substrates are indicated at the top of the figure. $(C)$ 293T cells were transfected with either an empty expression vector (negative control, lane 1), the indicated expression plasmids containing full-length HPK1 (lane 2), the HPK1 carboxy-terminal portion (HPK1-CD; lane 3), the kinase-defective HPK 1 mutant [HPK1-M(46), lane 4] (10 $\mu \mathrm{g}$ each). pVA1 $(10 \mu \mathrm{g})$ containing the adenovirus VAl RNA gene was also included in each transfection to enhance transient protein expression. The cells were harvested $48 \mathrm{hr}$ after transfection. After immunoprecipitation with anti-HPK 1 antibody, HPK 1 activity was determined by an immunocomplex kinase assay, using MBP as a substrate. The HPK1-CD and HPKl-M(46) constructs are shown in a schematic diagram in Fig. 4C. $(D)$ Phosphoamino acids of in vitro phosphorylated MBP were resolved electrophoretically in two dimensions using a TLC with two $\mathrm{pH}$ systems. The relative positions of unlabeled phosphoamino acids are indicated below the autoradiograph. (S) serine; (T) threonine; (Y) tyrosine.
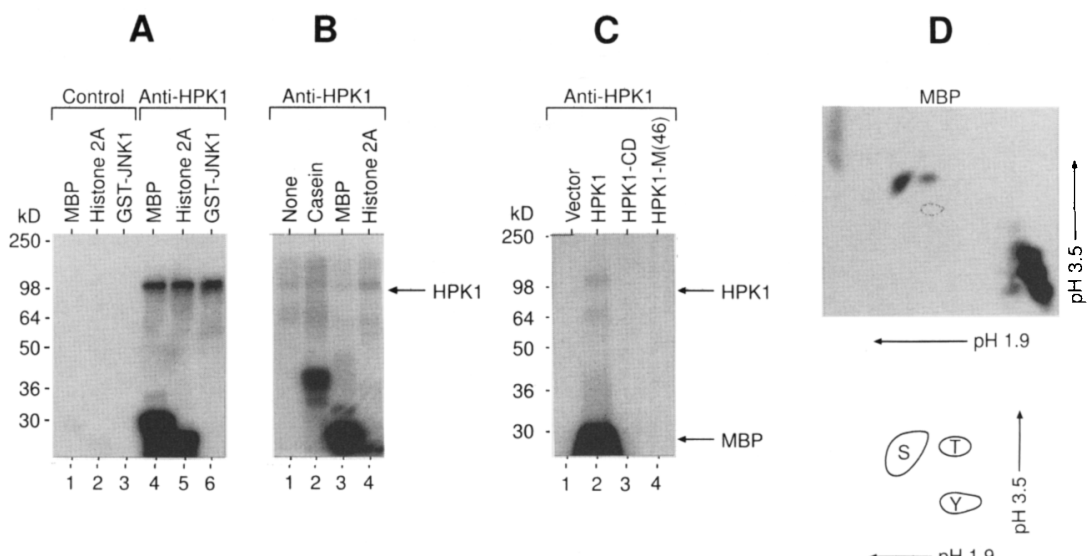
A

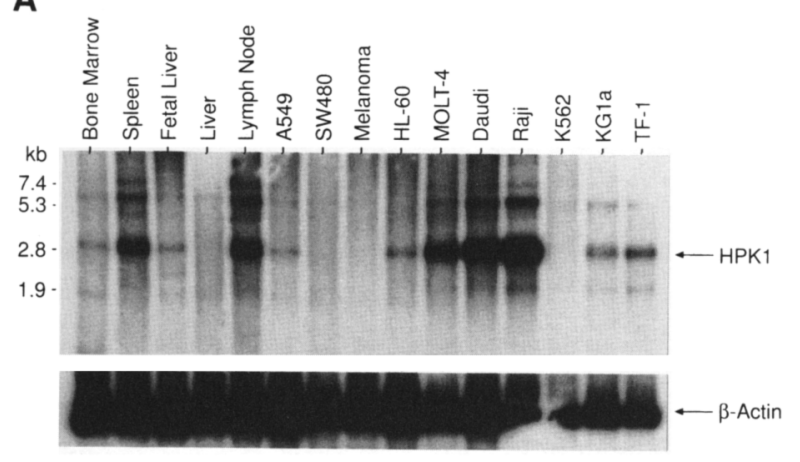

B

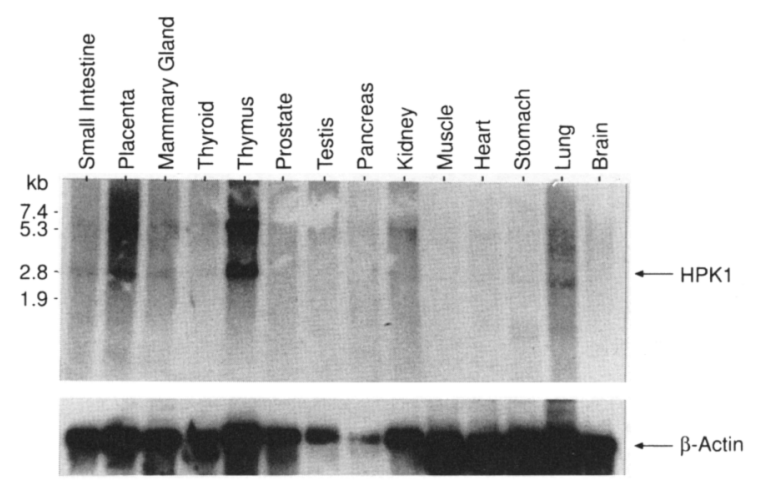

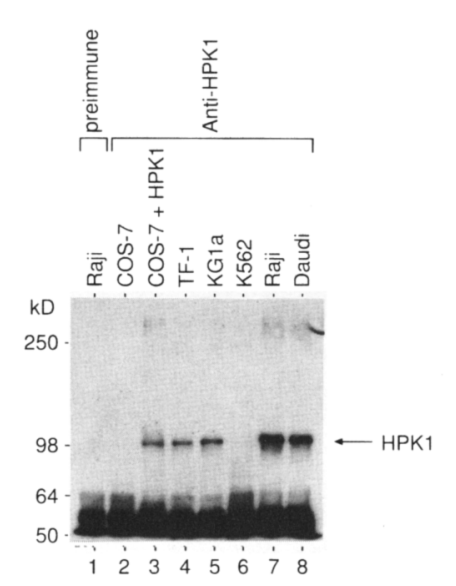

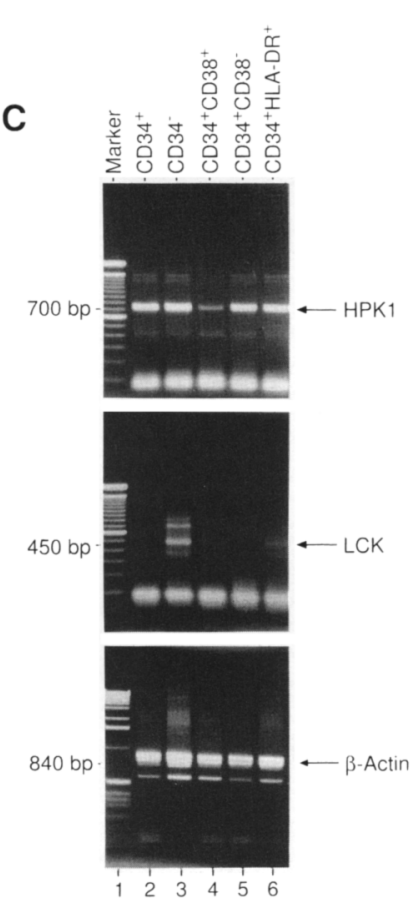

Figure 3. Expression pattern of human HPK1. (A) Northern blots of various human tissues and cell lines were probed with the HPK1 cDNA. As a control, the same blots were reprobed with human $\beta$-actin cDNA to check the integrity of the RNA (bottom). ( $B)$ Endogenous HPKl proteins were immunoprecipitated from lysates of various human hematopoietic cell lines with anti-HPKl antiserum or preimmune serum (negative control, lane 1). Subsequently HPKl proteins were detected by Western blot analysis using anti-HPKl antiserum. $(C)$ The relative expression of HPKl in human hematopoietic progenitor cell populations was analyzed by RT-PCR. First strand cDNAs were synthesized from total RNAs purified from various human hematopoietic cell populations from bone marrow or fetal liver. Subsequently, HPK1 (top) or Lck (middle) cDNAs were detected by PCR with HPK 1- or Lck-specific primers as described in Materials and Methods. The same samples were analyzed by PCR with human $\beta$-actin-specific primers to check the integrity of the cDNA or RNA (bottom). The specific PCR products are highlighted.

cells as well. As a control, Lck transcripts were also determined by RT-PCR, using two Lck-specific primers. As expected, Lck is expressed primarily in the CD34population with low-level expression in $\mathrm{CD} 34^{+}$, $\mathrm{CD} 34^{+} \mathrm{CD} 38^{+}$, and $\mathrm{CD} 34^{+} \mathrm{HLA}-\mathrm{DR}{ }^{+}$populations. The results confirm that the $\mathrm{CD} 34^{+} \mathrm{CD} 38^{-}$population contains mainly progenitor cells and stem cells. It remains unclear, however, whether HPKl is expressed in totipotent hematopoietic stem cells.

\section{HPK1 activates specifically the INK/SAPK signaling pathway}

Because HPKl may be involved in the mammalian MAPK signaling cascade, we investigated whether HPK1 could stimulate the JNK/SAPK signal transduction pathway. We tested this hypothesis by cotransfection of HPK 1 cDNA with JNK1 cDNA in 293T cells and assayed the INK1 kinase activity using an in-gel kinase assay with its physiological substrate c-Jun (Fig. 4A). The ingel kinase assay detected the apparent molecular mass of JNK1 (46 kD)-this demonstrated that the kinase activity was from JNK1 and not from other kinases that may have been associated with the JNK1 complex. Transfec- tion of HPK1 alone activated endogenous JNK1 to a level slightly higher than or similar to that of JNKl transfected alone in 293T cells (Fig. 4A, lanes 6,7). Although, as predicted, anisomycin activated the JNK1 kinase activity strongly in JNK1-transfected $293 \mathrm{~T}$ cells, cotransfection of HPKl with JNK1 in 293T cells elevated the INK1 kinase activity 10- to 15 -fold higher than that of INK1 transfected alone in 293T cells (Fig. 4A, lanes 8,9). As a control, vector alone was transfected into 293T cells, and no JNKl activity was detected (Fig. 4A, lane 5). Because conditioned media from the HPK1-transfected 293T cells failed to stimulate JNK1 activity in JNK1transfected 293T cells (data not shown), the activation of JNK 1 activity by HPK 1 was not attributable to induction by an autocrine loop. Furthermore, we showed that HPK 1 did not detectably phosphorylate c-Jun in an in-gel kinase assay, and it also did not complex with JNK1 directly by immunoprecipitation with anti-HPK1 antibody (Fig. 4A, lanes 1-4). As a control for JNK1 expression, an equal amount of each cell lysate was resolved by SDS-PAGE, and immunoblotted with anti-JNK1 antibody (Fig. 4A, bottom). Our preliminary result showed that HPK1 did not detectably stimulate p38-MAPK ki- 
Figure 4. Activation of JNK1 by HPK1. (A) $293 \mathrm{~T}$ cells were transfected with either an empty expression vector /negative control, lane 5) or the indicated expression plasmid containing HPK 1 or JNK1 cDNA (10 $\mu \mathrm{g}$ each). pVAl $(10 \mu \mathrm{g})$ containing adenovirus VAI RNA gene was also included in each transfection to enhance transient protein expression. The cells were harvested $48 \mathrm{hr}$ after transfection. As a positive control, $293 \mathrm{~T}$ cells transfected with INK 1 cDNA (lanes 3,8) were starved for 16 $\mathrm{hr}$, followed by treatment with anisomycin $(1 \mu \mathrm{g} / \mathrm{ml})$ for $1 \mathrm{hr}$. After immunoprecipitation with either anti-HPKl or anti-JNK1 antiserum, JNK1 activity was measured by in-gel kinase assays, using GST-c-Jun(1-193) as a substrate. As a control for JNK1 expression, an equal amount of each cell lysate $(200 \mu \mathrm{g})$ was resolved by $10 \%$ SDS-PAGE, and immunoblotted with anti-JNK1 antibody (bottom). (B) 293T cells were transfected with either an empty expression vector (negative control, lane 1) or the indicated expression plasmids $(10 \mu \mathrm{g}$ each). pVA1 $(10 \mu \mathrm{g})$ containing the adenovirus VA1 RNA gene was also included in each transfection to enhance transient protein expression. The cells were harvested $48 \mathrm{hr}$ after transfection. After immunoprecipitation with anti-JNKl antibody, JNKl activity was determined by an immunocomplex kinase assay, using GST-cJun(1-193) as a substrate. As a control for JNK1 expression, an equal amount of each cell lysate $(100 \mu \mathrm{g})$ was resolved by electrophoresis in a $10 \%$ SDS-PAGE, transferred to a PVDF membrane, and JNK1 protein was detected by Western blot analysis using anti-JNK 1 antibody. As a control for JNK1 expression, an equal amount of each cell lysate (200 $\mu \mathrm{g}$ ) was resolved by $10 \%$ SDS-PAGE, and immunoblotted with anti-JNKl antibody (bottom). (C) A schematic illustration depicts the domains and point mutations of HPKl included in the various constructs.

nase activity (data not shown). The results suggest that HPK 1 plays an important role in JNK1 activation and may be an upstream activator of JNK1.

To determine whether the observed INK1 activation was directly from HPK1 and not from other HPK1-associated or anti-HPK1 cross-reacted kinases, we constructed two HPK1 mutants by substituting the Lys-46 in the kinase domain with either Arg [designated HPK I$\mathrm{R}(46)]$ or Met [HPK1-M(46)], which may abrogate ATP binding (Fig. 4C). Although partial kinase activity was observed in HPK1-R(46)-transfected 293T cells (data not shown), no kinase activity was observed in HPK 1-M(46)transfected cells (Fig. 2C). Cotransfection of each of these mutant constructs with JNK1 in 293T cells showed that HPK1-M(46) failed to activate JNK1, whereas HPK1-R(46) still activated JNK1 activity partially (Fig. 4B, lanes 4,5). These results demonstrated that the observed JNK1 activation was from HPK1 and not from other HPK1-associated kinases or from crossreactive kinases precipitated by anti-HPK1 antibody. We further examined whether both the kinase domain and the carboxy-terminal portion of HPKl were required for JNK1 stimulation. We constructed two expression constructs containing the HPK1 kinase domain alone (amino acids 1-291) and the HPK1 carboxy-terminal domain (amino acids 292-833) containing the four prolinerich domains, designated $\mathrm{HPK} 1-\mathrm{KD}$ and $\mathrm{HPK} 1-\mathrm{CD}$, re- spectively (Fig. 4C). Cotransfection of each of these constructs with JNK1 in 293T cells indicated that the HPK1 kinase domain alone was sufficient to activate JNK1 activity, whereas the HPK1 carboxy-terminal domain alone failed to activate JNK1 (Fig. 4B, lanes 6,7). As a control for JNKl expression, an equal amount of each cell lysate was resolved by SDS-PAGE, and immunoblotted with anti-JNK 1 antibody (Fig. 4B, bottom).

\section{HPK1 elevates AP-1 activity in vivo}

To establish whether the effect of JNK1 activation through HPKl exerts its physiological function in vivo, we tested whether HPKl could activate the c-Jun responsive enhancer element (Fig. 5). We cotransfected the fulllength HPK 1 expression vector (pBK-HPK1) with a chloramphenicol acetyltransferase (CAT) reporter construct containing multiple c-Jun-binding sites $(5 \times$ TRE-CAT) into $293 \mathrm{~T}$ cells. As a positive control, the $5 \times$ TRE-CAT construct alone was transfected into $293 \mathrm{~T}$ cells, and the transfected cells were then stimulated with $10 \mathrm{nM}$ of phorbol 12-myristate 13-acetate (PMA) for $24 \mathrm{hr}$. As shown in Figure 5, CAT assays showed that HPK1 increased AP-1-mediated transcriptional activity $\sim 30$-fold (lane 2), and PMA also stimulated activator protein 1 (AP-1) activity $\sim 68$-fold (lane 5 ). We also cotransfected $5 \times$ TRE-CAT with either HPK1-CD or HPK1-KD into $293 \mathrm{~T}$ cells. CAT assay results indicated that the HPKl 


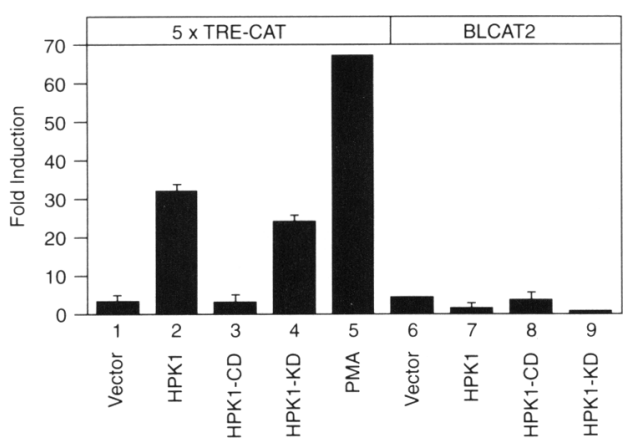

Figure 5. Activation of AP-1 activity by HPK1. The $5 \times$ TRECAT or TK-CAT (pBLCAT2) reporter construct ( $3 \mu \mathrm{g}$ each) was transfected into $293 \mathrm{~T}$ cells with an empty vector (lanes 1,6 ), HPKl (lanes 2,7), HPK1-CD (lanes 3,8), or HPK1-KD (lanes 4,9) $(10 \mu \mathrm{g}$ each). In lane 5 , the empty vector-transfected cells were stimulated with $10 \mathrm{nM}$ of PMA for $24 \mathrm{hr}$. The cells were harvested $48 \mathrm{hr}$ after transfection, and the CAT activities were measured and compared with that of the empty vector. The pCMV- $\beta$-Gal reporter plasmid (l $\mu \mathrm{g})$ was used in all the transfection assays to normalize variations in transfection efficiency. The results are expressed as fold induction.

kinase domain alone was sufficient, albeit with slightly lower activity, to activate AP- 1 activity (25-fold induction, lane 4), whereas the HPKl carboxy-terminal domain alone failed to activate AP-1 activity (lane 3). On the other hand, HPKl did not activate the control TKCAT reporter construct pBLCAT2, which does not contain the c-Jun-binding site (lane 7). These results suggest that HPKl activates JNK1, which in turn augments phosphorylated c-Jun to increase transcription in vivo.

\section{HPK1 associates with and phosphorylates MEKK1}

It is believed that MEKK1 stimulates MKK4/JNKK/SEK, which in turn activates JNKs/SAPKs (Minden et al. 1994; Yan et al. 1994; Derijard et al. 1995). Because it appears that HPK1 does not complex or phosphorylate JNK1 directly (see Fig. 2A, lane 6), we examined whether HPKl could act on the upstream activator MEKKl. Cotransfection of MEKK1 cDNA (pCI-HA-MEKK1) with a full-length HPK1 cDNA (pBK-HPK1) or HPK1CD plasmid in $293 \mathrm{~T}$ cells showed that anti-MEKK1 antibody immunoprecipitated specifically full-length HPK1 together with MEKK1 (Fig. 6A, lane 2). In contrast, the addition of anti-MEKKl antibody did not immunoprecipitate the HPK1 carboxy-terminal domain together with MEKK1 (Fig. 6A, lane 3). This result correlates well with the finding that the HPK1 carboxy-terminal domain does not activate JNK1 in cotransfection experiments as described above. As controls, anti-HPKl antibody immunoprecipitated both HPKl and the HPK1 carboxy-terminal domain expressed in the transfected cells (Fig. 6A, lanes 4,5), indicating that the HPKl carboxyterminal domain is soluble and is expressed at least at the same level as HPKl in the transfected cells. This control argues strongly against the possibility that poor washing failed to remove an overexpressed amount of HPK1 in the immunoprecipitates. Similarly, anti-HPKl antibody immunoprecipitated MEKK1 together with full-length HPK1, but not the HPK1 carboxy-terminal domain (Fig. 6B, lanes 2,3). As controls, anti-MEKK1 antibody immunoprecipitated MEKK1 expressed in the transfected cells (Fig. 6B, lanes 4,5), showing that MEKK1 is expressed at about the same level in both transfected cells. These results indicate that the fulllength HPK1 is specifically associated with MEKK1. Moreover, an immunocomplex kinase assay revealed that HPK1 phosphorylated directly MEKK1 in vitro (Fig. 6C). As controls, the HPK1 carboxy-terminal domain (HPK1-CD) and the kinase-defective HPK1 mutant [HPK1-M(46)] failed to phosphorylate the substrate MEKK I (Fig. 6D), indicating that the HPK1 kinase activity observed is not attributable to the presence of nonspecific kinases in the immune complexes. As a control for HPK1 expression, an equal amount of each cell lysate was resolved by SDS-PAGE, and immunoblotted with anti-HPK1 antibody (Fig. 6D, bottom). In addition, phosphoamino acid analysis of in vitro phosphorylated MEKK1 detected P-Ser and P-Thr only (Fig. 6E). However, we and others found that the MEKK1 proteins (fulllength or truncated) expressed in either bacteria or mammalian cells still display high basal activity in vitro $(\mathrm{Xu}$ et al. 1996; B. Su, M. Karin, and D. Templeton, pers. comm.; data not shown); hence, it is not feasible at the present time to demonstrate the direct activation of MEKK1 kinase activity by HPKl in vitro. Taken together, our results strongly suggest, but do not prove, that HPK1 may be a direct modulator of the MEKK1 protein kinase.

\section{Inhibition of HPK1-induced JNK activation by dominant-negative MEKK1 or SEK1 mutant}

To show that HPK1 is an upstream activator of MEKK1, we used the dominant-negative MEKKl mutant (MEKK1-KR) and tested the effect of the MEKK1-KR mutant on the JNK1 activation by HPK1 in a cotransfection assay (Fig. 7A). 293T cells were cotransfected with HPK1 plus JNK1 alone, or HPK1 plus JNK1 and either wild-type or mutant MEKK1 expression plasmid. JNK1 kinase activities were determined by immunocomplex kinase assays using anti-JNKl antibody. We found that the dominant-negative MEKK1 mutant (MEKK1-KR) blocked the HPK1-induced JNK1 kinase activity (Fig. 7A, lanes 2,4), whereas wild-type MEKK1 enhanced the HPK1-induced JNK1 activity (lanes 2,3). As a control for JNKl expression, an equal amount of each cell lysate was resolved by SDS-PAGE, and immunoblotted with anti-JNK1 antibody (Fig. 7A, bottom). This result indicates that MEKK1 is downstream of HPK1 in the kinase cascade.

Because SEK (also called MKK4 or JNKK) is the downstream kinase of MEKK1, we also examined whether the dominant-negative SEK (SEK-AL) could block the HPK1induced JNK1 kinase activity (Fig. 7B). 293T cells were cotransfected with HPKl plus JNK1 alone, HPK1 plus 
Figure 6. HPK1 associates with and phosphorylates MEKKl. (A) 293T cells were cotransfected with HA-tagged MEKKl cDNA (10 $\mu \mathrm{g}$ ) with either the empty vector (lane 1) or the expression vectors containing either full-length HPK1 cDNA (HPK1, lane 2) or the HPKl carboxy-terminal portion (HPK1-CD; lane 3) (10 $\mu \mathrm{g}$ each plasmid). The cells were harvested $48 \mathrm{hr}$ after transfection. After immunoprecipitation with either anti-MEKK1 monoclonal antibody or anti-HPK1 antibody (positive controls, lanes 4,5 I, HPKl protein was detected by Western blot analysis using anti-HPK1 antibody. The HPK1 protein and IgG heavy chain are marked. $(B)$ Cell lysates as indicated were immunoprecipitated with either anti-HPKl antibody or anti-MEKKl monoclonal antibody (positive controls, lanes $4,5)$, and MEKK1 protein was detected by Western blot analysis using anti-HA monoclonal antibody. The MEKKl protein and IgG heavy chain are indicated. $(C)$ Endogenous HPK 1 was immunoprecipitated from Daudi cells with either control serum or anti-HPK1 antibody and subjected to an immunocomplex kinase assay in the presence of the indicated substrates. The HPK 1 and human MEKK1(1-301) phosphoproteins are indicated. $(D) 293 \mathrm{~T}$ cells were transfected with either an empty expression vector (negative control, lane 1), the indicated expression plasmids containing full-length HPK1 (lane 2) or HPK1-CD (lane 3), or the kinase-defective HPK1 mutant [HPK]$\mathrm{M}(46)$, lane 4) (10 $\mu \mathrm{g}$ each). pVAl (10 $\mu \mathrm{g})$ containing adenovirus VAl RNA gene was also included in each transfection to enhance transient protein expression. The cells were harvested $48 \mathrm{hr}$ after transfection. After immunoprecipitation with antiHPKl antibody, HPKl activity was determined by an immunocomplex kinase assay, using MEKK1(1-301) as a substrate. As a

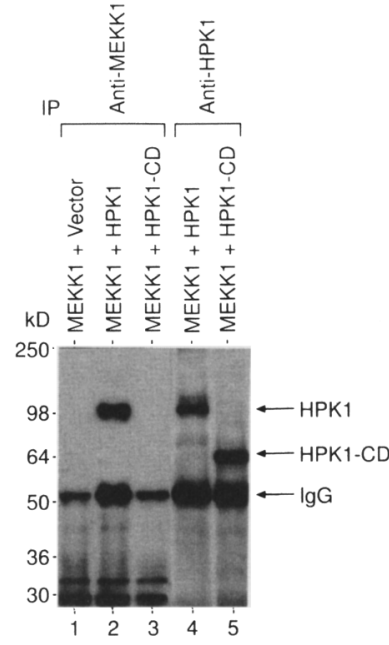

C

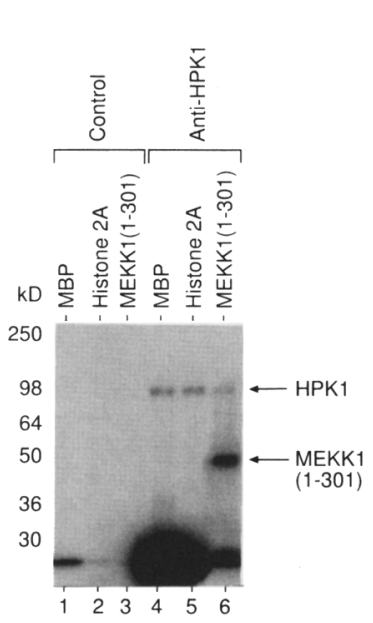

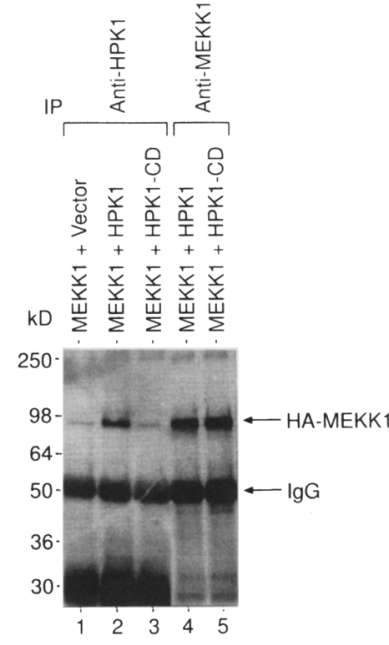

D

$\mathbf{E}$

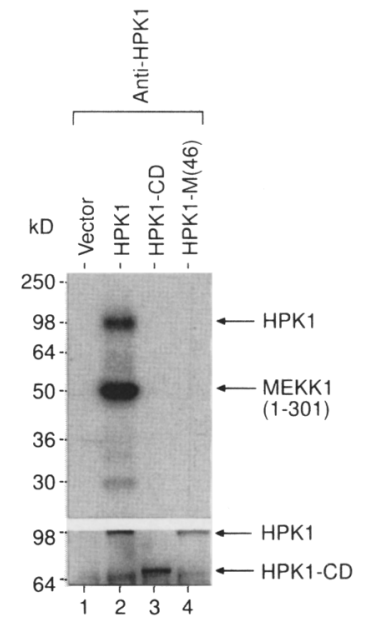

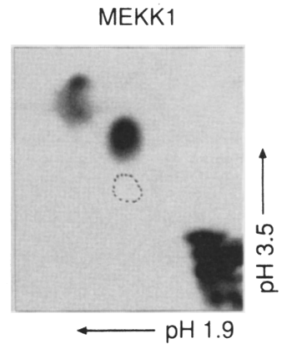

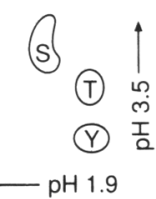
control for HPKl expression, an equal amount of each cell lysate was immunoprecipitated with an anti-HPK1 antibody, and HPK1, HPK 1-CD, and HPK 1-M(46) proteins were detected by Western blot analysis using the same anti-HPK1 antibody (bottom). HPK1 and HPK1-CD proteins are indicated. (E) Phosphoamino acids of in vitro phosphorylated MEKK1 were analyzed. Relative positions of unlabeled phosphoamino acids are indicated below the autoradiograph. $(\mathrm{S})$ serine; $(\mathrm{T})$ threonine; $(\mathrm{Y})$ tyrosine.

INK1 and either wild-type or mutant SEK1 expression plasmid, and the JNK1 kinase activities were determined by immunocomplex kinase assays. As a control for JNK1 expression, an equal amount of each cell lysate was resolved by SDS-PAGE, and immunoblotted with antiJNK1 antibody (Fig. 7B, bottom). We found that the dominant-negative SEK1 mutant (SEK-AL) blocked partially the HPK1-induced JNK1 kinase activity (Fig. 7B, lanes $2,3 \mid$; this may be attributable to the presence of other unidentified SEK/MKK4/INKK isoforms (R.J. Davis, pers. comm.) that can be activated by HPKl. Interestingly, an addition of the wild-type SEK1 expression plasmid did not further increase the HPKl-induced JNK1 activity (lanes 2,4 ), implying that the levels of endoge- nous SEK1 were in excess in mediating INK1 activation by HPK1 in 293T cells. This result indicates MKK4/ SEK/JNKK is downstream of HPK1 in the kinase cascade. Taken together, our data indicate that HPK1 can activate the MEKK1-MKK4/SEK/JNKK-JNK kinase cascade.

\section{Rac1 and Cdc42 are not the upstream regulators of HPK1}

Racl and Cdc42 activate PAK1, which in turn regulates the JNK/SAPK signaling pathway (Coso et al. 1995; Minden et al. 1995); hence, we tested whether HPK1 could also bind to small GTPases Racl, Cdc42, Ras, and RhoA 
A

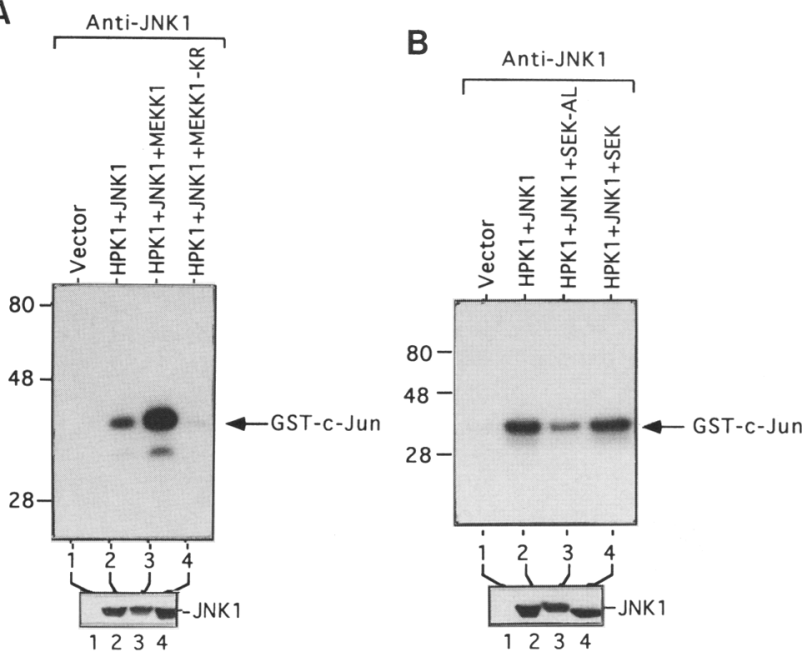

Figure 7. Activation of MEKK1 and SEK1 by HPK1. (A) 293T cells were cotransfected with empty vector alone (lane 1), HPK1 (pCIneo-HPK1) plus JNKl alone (pCIneo-JNK1, lane 2), or HPKl plus INK1 and either wild-type (pUna3-MEKK-FL-WT, lane 3) or mutant MEKKl (pUna3-MEKK-KR-FL, lane 4) expression plasmid. JNK1 kinase activities were determined by immunocomplex kinase assays using anti-JNK1 antibody. (B) 293T cells were cotransfected with an empty vector alone (lane 1 ), HPK1 plus JNK1 alone (lane 2), or HPK1 plus JNK1 and either mutant (pEBG-SEK1-AL, lane 3) or wild-type (pEBG-SEK1, lane 4) SEK1 expression plasmid. The JNKl kinase activities were determined by immunocomplex kinase assays using antiJNKl antibody. GST-cJun(1-79) fusion protein was used as the substrate for JNK1. As a control for JNKl expression, an equal amount of each cell lysate $(20 \mu \mathrm{g})$ was resolved by $10 \%$ SDSPAGE and immunoblotted with anti-JNK1 antibody (bottom).

directly. KGla and Raji whole-cell lysates were passed through glutathione-Sepharose columns preloaded with GTP- $\gamma$-S and each of the GST-GTPase fusion proteins including GST-Rac1, GST-Cdc42, GST-Ras, and GSTRhoA. The bound proteins were eluted, electrophoresed, transferred to a polyvinylidene difluoride (PVDF) membrane, and probed with either anti-PAK1 or anti-HPK1 antibody. The $64-\mathrm{kD}$ PAK1 proteins were detected in the GST-Racl and GST-Cdc42, but not in the GST-Ras and GST-RhoA, bound fractions from KGla cell lysate (Fig. $8 \mathrm{~A}$ ) as expected, whereas no $97-\mathrm{kD}$ HPK1 proteins were detected in the eluents from all the glutathione-Sepharose columns preloaded with GST- $\gamma$-S and individual GST-GTPases (Fig. 8B). To confirm further that Racl and Cdc42 are not the upstream regulators of HPK1, we tested the effects of the activated Racl and Cdc42 on HPK1 in a transient transfection assay (Fig. 8C). HPK1 expression plasmid was cotransfected with each of the small GTPase plasmids encoding the activated RhoA, Racl, Cdc42, and Ras, respectively. HPKl activity was examined by immunocomplex kinase assay using the MEKK1(1-301) recombinant protein as the substrate. We found that activated small GTPases, including Racl and Cdc42, did not modulate HPK1 kinase activity (Fig. 8C, lanes $1-5$ ). As a positive control, JNK1 was cotransfected
A

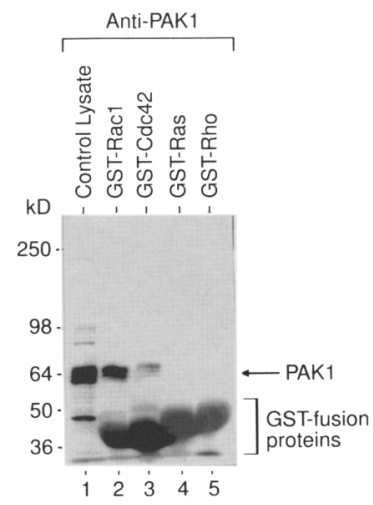

B
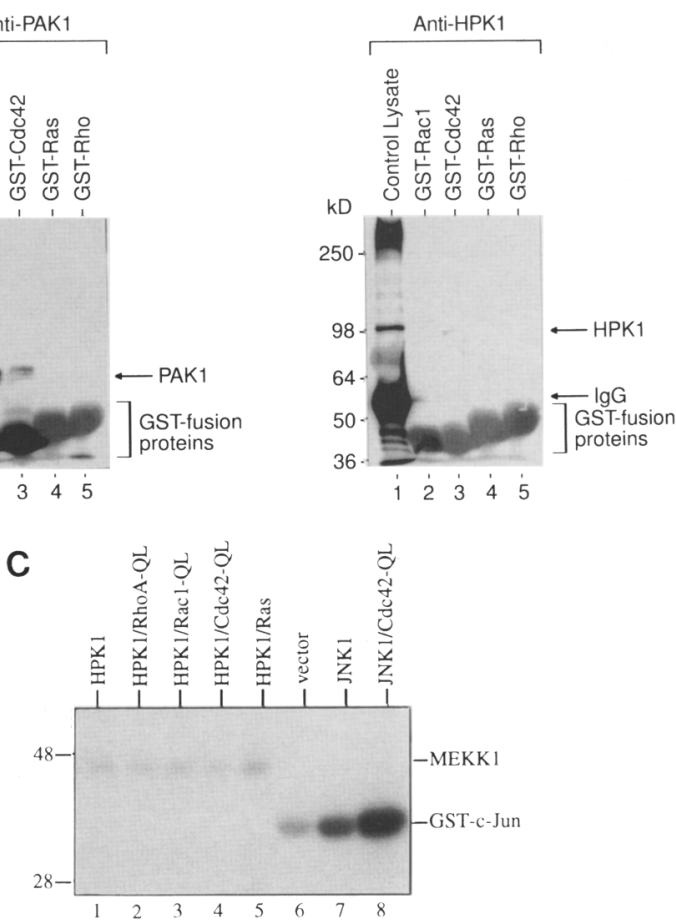

Figure 8. Racl and Cdc42 are not the upstream regulators of HPK 1. (A) Detection of PAK1 binding to GST-Racl and GSTCdc42 using affinity chromatography. KGla whole-cell lysates were run through the glutathione-Sepharose column preloaded with GTP- $\gamma$-S and individual small GTPases (GST-Rac1, GSTCdc42, GST-Ras, or GST-RhoA) as indicated, and the bound proteins were eluted and immunoblotted with anti-PAKl antibody. As a positive control for PAKl protein, an aliquot of KGla cell lysate was included (lane 3). PAK1 protein is highlighted. (B) Examination of HPKl binding to small GTPases GST-Racl, GST-Cdc42, GST-Ras, and GST-RhoA using affinity chromatography. Raji whole-cell lysate was passed through the GSTGTPase fusion protein affinity column as indicated, and the bound proteins were immunoblotted with anti-HPKl antibody. As a positive control for HPKl, an aliquot of Raji lysate was immunoprecipitated with an anti-HPK 1 antibody, and HPK 1 protein was detected by Western blot analysis using the same antibody \{lane 1). HPK1 protein and IgG heavy chain are indicated. (C) $293 \mathrm{~T}$ cells were transfected with pCIneo-HPK1 plasmid alone (lane 1 ) or pCIneo-HPK1 plasmid plus individual small GTPase plasmids encoding the activated RhoA, Racl, Cdc42, and Ras, respectively (lanes 2-5). HPK1 activity was examined by immunocomplex kinase assay using anti-HPKl antibody. MEKK1(1-301) recombinant protein $(1 \mu \mathrm{g})$ was used as the substrate for HPK1. As a positive control, $293 \mathrm{~T}$ cells were transfected with vector alone (lane 6), pCIneo-INK1 plasmid alone (lane 7), or pCIneo-INKl plasmid plus the activated Cdc42 plasmid, pCDN3-Cdc42-QL (lane 8), and JNK1 kinase activity was studied by immunocomplex kinase assay using anti-JNK1 antibody. GST-cJun(1-79) fusion protein $(5 \mu \mathrm{g})$ was used as the substrate for JNKl.

with vector alone (lane 7) or the activated Cdc42 plasmid (lane 8 ), and JNK1 kinase activity was studied by immunocomplex assay using GST-cJun(1-79) as the substrate. 
As expected, Cdc42 activated JNK1 kinase activity (Fig. $8 \mathrm{C}$, lanes $6-8$ ). These results are consistent with our observation that the HPK1 protein does not contain the putative Racl/Cdc42-binding domain found in PAK (Manser et al. 1994; Burbelo et al. 1995), indicating that Racl and Cdc42 are not the upstream effectors that regulate HPKl function.

\section{Discussion}

We have cloned molecularly a novel protein kinase termed HPK1 that is expressed predominantly in hematopoietic tissues including early progenitor cells. To date, HPK1 is the first tissue-specific PAK-like kinase that has been identified. GCK was identified originally as a kinase expressed preferentially in the germinal center B cells, but is also expressed in many other tissues, including the brain, lung, placenta, kidney, pancreas, heart, liver, and skeletal muscle (Katz et al. 1994). Similarly, PAK65 was isolated initially from the brain (Manser er al. 1994), but its mRNAs are distributed ubiquitously in human tissues, with higher levels in skeletal muscle, ovary, spleen, and thymus (Martin et al. 1995). We provide evidence that HPK1 activates JNK specifically. Furthermore, we show that HPK1 enhanced strongly AP-1-mediated transcriptional activity in vivo, which further supports the finding that HPK1 is a functional activator of the INKs/SAPKs signaling pathway. Although three members of the PAK family have been identified in mammalian cells, HPK1 appears to be related distantly to PAK as they share no significant homology outside of the kinase domains and their structures are distinct. Moreover, HPK 1 does not contain the putative Racl/Cdc42-binding domain found in PAK (Manser et al. 1994; Burbelo et al. 1995) and did not bind to Racl and Cdc42 (Fig. 8), indicating that Racl/Cdc42 does not act on HPKl directly. This result suggests that HPK 1 may be involved in a novel Racl/Cdc42-independent JNK1 signaling pathway. The upstream effectors that regulate the function of HPK1 are yet to be fully elucidated. In fact, we found that HPKl was not regulated by the known JNK1-inducing agents such as UV-C, TNF- $\alpha$, and the protein synthesis inhibitor anisomycin (data not shown). We suggest that HPK1 may be involved in previously unidentified stress signaling pathways and the identification of HPK1 may provide a key to unravel these novel pathways. One interesting structural feature of HPK 1 and the PAK family is that they contain four proline-rich domains (the putative $\mathrm{SH} 3$-domain binding sites), and the relative locations of these proline-rich domains are not conserved between HPKl and PAKs (Fig. 1D). It has been shown recently that the putative SH3domain binding sites of mouse PAK3 can bind to the SH3 domains of phospholipase $\mathrm{C} \gamma$ and an adapter protein Nck (Bagrodia et al. 1995b). These SH3-domain binding sites have been implicated to be involved in the regulation and localization of these protein kinases. It will be interesting to determine whether the four proline-rich domains are important for HPK1 function.

Because Racl and Cdc42 activate a STE20 homolog,
PAK65, and also regulate JNKs/SAPKs activity, it has been postulated that either PAKs or related kinases may connect Racl and Cdc42 to the MEKK1-MKK4/SEK/ JNKK-JNK/SAPK pathway. To date, the identity of the molecules that control MEKKl directly still remains unclear. Here, we provide evidence that HPKl can associate with and phosphorylate MEKK1 directly, and JNK1 activation by HPK1 can be blocked by a dominant-negative MEKK1 or SEK1 mutant. This indicates that HPK1 can activate MEKK1 directly; therefore, HPKl is an upstream activator of the MEKK1-MKK4/SEK/INKKJNK/SAPK hierarchy (Fig. 9). Recently, multiple MEKK homologs (MEKK2 and MEKK3) have been isolated (Blank et al. 1996; B. Su and M. Karin, pers. comm.). Furthermore, several other MKK4/SEK/JNKK-activating kinases le.g., TAK1, MUK, MLK/SPRK, or Tpl-2; Yamaguchi et al. 1995; Hirai et al. 1996; Rana et al. 1996; Salmeron et al. 1996) have also been identified. Therefore, we wish to emphasize that (1) HPKl should not be the only upstream kinase that can activate MEKKl, especially in nonlymphoid cells, and (2) HPKl may also be able to activate other MEKK-like kinases. Further studies using HPK 1 and various members of the MEKK family and other MKK4/SEK/INKK-activating kinases (e.g., TAK1, MUK, MLK/SPRK, or Tpl-2) will be necessary to reveal the relative specificities of various JNK signaling cascades.

The regulatory network controlling the formation, function, and balance of blood cells is highly complex. It includes precisely coordinated new cell production, accurate lineage commitment, correct initiation and com-

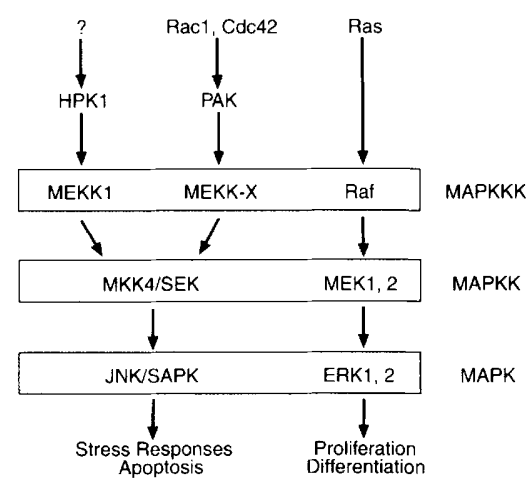

Figure 9. Proposed parallel signal transduction pathways for activation of JNK/SAPK. In the JNK/SAPK signaling pathway, JNK/SAPK, MKK4/SEK, and MEKK1 represent the first three hierarchical levels, and we suggest that HPKl represents an upstream kinase in this cascade. PAK has been suggested to be an upstream kinase in this cascade (Bagrodia et al. 1995a; Zhang et al. 1995); however, it may actually activate MEKK-X (e.g., MEKK2 and MEKK3; Blank et al. 1996). Unlike PAK, HPK1 activation is independent of Racl and Cdc42. In the ERK signaling pathway, only three levels have been identified, represented by ERK1 or ERK2, MEK1 or MEK2, and Raf (Marshall 1995). Ras regulates ERKs by acting directly on Raf. Potential cross-talks among these signaling systems are not ruled out in this diagram. The pathway connecting cell surface receptors to HPKl are yet to be fully elucidated. 
pletion of cell maturation, controlled release of mature cells, maintenance of circulating blood cell levels throughout the body, selective exit of some (e.g., leukocytes) but not all cell types to the tissues, functional activation of such cells when necessary, coupled finally with a system for detecting and eliminating (e.g., cell death) senescent or effete cells. The mechanisms of most of these processes remain largely unknown. Although several activators of JNKs/SAPKs have been identified, the mechanism underlying this pathway in the hematopoietic system is unclear, but it is a key in understanding the molecular basis of differentiation or apoptosis of blood cells. The identification and isolation of a novel MEKK1-JNK upstream regulator expressed specifically in hematopoietic cells including early progenitor cells that undergo lineage determinations may provide a means for studying the signaling mechanisms governing the control of hematopoietic differentiation or cell fate determination.

\section{Materials and methods}

\section{cDNA cloning}

A mouse partial cDNA was identified from a subtracted cDNA library between a granulocyte-macrophage progenitor and an erythrocyte-megakaryocyte progenitor (N.N. Iscove, pers. comm.), using the subtractive hybridization technique (Brady et al. 1995|. This mouse cDNA was used as a probe to screen $\lambda$ DR2 human fetal liver and human bone marrow cDNA libraries, according to the manufacturer's instructions (Clontech). Several positive clones were obtained after screening $4 \times 10^{6}$ phages. The cDNA inserts of these phage clones were converted subsequently in vivo into pDR2 plasmid vector by infecting an Escherichia coli AMl strain with the candidate recombinant phage, according to the manufacturer's instructions. After analysis of the inserts, two clones isolated from a human fetal liver cDNA library contained the largest inserts $(\sim 2.8 \mathrm{~kb})$ that were presumably near full-length. DNA sequencing of both strands of each clone was performed using a PCR procedure using fluorescent dideoxynucleotides and a model 373A automated sequencer (Applied Biosystems).

\section{Plasmids, antibodies, and proteins}

Full-length HPKl (FL-1) cDNA was cloned into the expression vector $\mathrm{pBK}-\mathrm{CMV}$ (Stratagene) between the NheI and NotI sites, designated $\mathrm{pBK}-\mathrm{HPK} 1$, and the expression vector $\mathrm{pSR} \alpha$-neo between the $X b a \mathrm{I}$ and NotI, designated pSR $\alpha$-HPK1. Full-length JNK1 cDNA was cloned into the expression vector pCI-neo (Promega) between the SalI and NotI sites, designated pCIINK1. The HPK1 kinase domain (amino acids 1-291) and the carboxy-terminal domain (amino acids 292-833) were obtained by the PCR technique using full-length HPKI cDNA as a template and cloned into the expression vector $\mathrm{pCI}$ (Promega), designated pCI-HPK1-KD and pCI-HPKl-CD, respectively. A PCR-based procedure was used to insert a Sall site and an hemagglutinin antigen (HA) tag (YPYDVPDYASL) at the $5^{\prime}$-end and NotI site at the 3 '-end of full-length MEKK1 cDNA (Russell et al. 1995; kindly provided by Dr. G.L. Johnson, National Jewish Center for Immunology and Respiratory Medicine, Denver, $\mathrm{CO}$, and the resulting PCR products were subcloned into the expression vector $\mathrm{pCI}$ between the corresponding restriction sites, designated pCI-HA-MEKK1. The sequences of these PCR constructs were confirmed by automated sequencing. The pUna3-FL-MEKK-WT and pUna3-FL-MEKK-KR plasmids were kindly provided by Dr. D. Templeton (Case Western Reserve University, Cleveland, OH). The mammalian SEK1 (wild-type and mutant) expression plasmids pEBG-SEK1 and pEBG-SEK1AL, were kindly provided by Dr. L.I. Zon (Children's Hospital, Boston, MA|. The GST-JNK1 plasmid was described previously (Meyer et al. 1996). GST-cJun(1-79) was a gift from Dr. M. Karin (University of California, San Diego, San Diego, CA). GST-cJun(1-193) was constructed by inserting the PmlI-SfiI fragment of the pRSVcJun plasmid into the SmaI site of the pGEX $-4 \mathrm{~T} 3$ fusion vector. The pVAl plasmid containing the adenovirus VAl RNA gene in pUC18 was described previously (Yoshinaga et al. 1987). The CAT reporter constructs $5 \times$ TRECAT was kindly provided by Dr. J. Bruder (GenVec, Rockville, MD; Angel et al. 1987). The GST-Racl fusion plasmid was a kind gift from Dr. A. Polverino (Amgen, Thousand Oaks, CA). The GST-Cdc42Hs, GST-RhoA, and GST-Ras fusion plasmids (Bagrodia et al. 1995b) were kindly provided by Dr. R.A. Cerione (Comell University, Ithaca, NY). The pcDNA3-RaclQL, pcDNA3-RhoA-QL, and pcDNA3-Cdc42-QL plasmids (Coso et al. 1995), encoding activated Rac1, Cdc42, and RhoA GTPases, respectively, were kindly provided by Dr. J.S. Gutkind (National Institutes of Health, Bethesda, MD). The pT22 plasmid, encoding an activated Ras oncogene, was described previously (Finlay et al. 1988). Polyclonal antisera were raised against synthetic peptides of human HPK1 or JNK1 in rabbits (Chen et al. 1996). Anti-MEKKl(43-Y) antibody, anti-PAK65 antibody, and purified human MEKK1(1-301) polyhistidine fusion proteins were purchased from Santa Cruz Biotechnology. Anti-HA monoclonal antibody was purchased from Berkeley Antibody Co. The GST fusion proteins were purified by affinity chromatography on glutathione-Sepharose $4 \mathrm{~B}$ (Pharmacia) according to the manufacturer's instructions.

\section{Northern blot analysis}

Total RNA from cultured human cell lines was isolated by standard methods using guanidinium thiocyanate, and poly $(\mathrm{A})^{+}$ RNA was selected with oligo(dT)-cellulose chromatography as described (Sambrook et al. 1989). Poly(A) ${ }^{+}$RNAs from 19 human tissues and eight cancer cell lines were obtained from Clontech Laboratories. Each sample $(2 \mu \mathrm{g})$ was denatured and electrophoresed on a $1.2 \%$ agarose gel containing formaldehyde and then transferred to a nylon membrane (Amersham) in $20 \times$ SSPE as described (Sambrook et al. 1989). HPK1 cDNA was labeled with $\left[{ }^{32} \mathrm{P}\right] \mathrm{dCTP}$ to a specific activity of $10^{8} \mathrm{dpm} / \mu \mathrm{g}$. Membranes were hybridized with the HPK $1 \mathrm{cDNA}$ probe, then washed at high stringency, at $65^{\circ} \mathrm{C}$ in $0.2 \times$ SSPE, $0.1 \%$ SDS, and subjected to autoradiography.

\section{$R T-P C R$}

RNA was extracted from the freshly sorted (FACScan) hematopoietic cells by the guanidinium thiocyanate phenol chloroform method using the Total RNA Separator Kit (Clontech). First-strand cDNA was synthesized with oligo $(\mathrm{dT})_{25}(\mathrm{dN})$ primer and MMLV reverse transcriptase (RNase $\mathrm{H}^{-}$) using the Great Length cDNA Synthesis Kit (Clontech). PCR was performed with $1 \mu \mathrm{g}$ of each cDNA reaction mixture and two primers in $100 \mu \mathrm{l}$ of PCR buffer containing $20 \mathrm{~mm}$ Tris- $\mathrm{HCl}(\mathrm{pH} 8.75), 10$ $\mathrm{mM} \mathrm{KCl}, 10 \mathrm{~mm}\left(\mathrm{NH}_{4}\right)_{2} \mathrm{SO}_{4}, 2 \mathrm{~mm} \mathrm{MgSO}, 0.1 \%$ Triton X-100, $0.1 \mu \mathrm{g} / \mu \mathrm{l} \mathrm{BSA}, 0.2 \mathrm{~mm}$ deoxynucleotide triphosphates, and 5 units of Taq Plus DNA polymerase (Stratagene). The sequences of the human HPK1, Lck, and $\beta$-actin (control) oligonucleotide primers were as follows: HPK1-a, 5'-TCAGATTG- 
GCTGACT-TTGGCATCTCGG-3'; HPK1-b, 5'-GATGTCCACGTCGTCATAGTCATCGTC-3'; Lck-a, 5' -CTGCCAACATTCTGGTGTCTGACACCC-3'; Lck-b, 5'-CCGTGAAGAAGTCCTCC-AGCACACTGC- 3 ; $\beta$-actin-a, $5^{\prime}$-ATCTGGCACCACACCTTCTACAATGAGCTGCG-3'; and $\beta$-actin-b, $5^{\prime}$-CGTCATACTCCTGCTTGCTGATCCACATCTGC-3'. Amplifications were performed in an automated thermocycler for $40 \mathrm{cy}$ cles consisting of $30 \mathrm{sec}$ at $94^{\circ} \mathrm{C}$ (denaturation), $1 \mathrm{~min}$ at $65^{\circ} \mathrm{C}$ (annealing), and $30 \mathrm{sec}$ at $72^{\circ} \mathrm{C}$ (extension). The final cycle was followed by a $5-\min$ extension at $72^{\circ} \mathrm{C}$. After amplification, the PCR products $(10 \mu \mathrm{g})$ were electrophoresed through a $2 \%$ SeaKem (FMC) agarose gel, and the PCR products were visualized directly in ethidium bromide-stained gels.

\section{Cell culture, transfections, and CAT assays}

293 T or COS-7 cells were grown in Dulbecco's modified Eagle's (DME) medium supplemented with $10 \%$ fetal bovine serum (FBS). Cells to be transfected were plated the day before transfection at a density of $2 \times 10^{6}$ cells per $100-\mathrm{mm}$ dish. The $293 \mathrm{~T}$ cells were cotransfected with expression plasmids $(10 \mu \mathrm{g}$ each plasmid per dish) as indicated with or without pVAl (10 $\mu$ g per dish) to enhance transient protein expression, using the calcium phosphate precipitation protocol (Specialty Media, Inc.). For anisomycin stimulation, $293 \mathrm{~T}$ cells were starved in DME medium containing $1 \%$ FBS for $16 \mathrm{hr}$, then treated with anisomycin 11 $\mu \mathrm{g} / \mathrm{ml}$ ) for $1 \mathrm{hr}$. For HPK 1 protein expression, COS-7 cells were transfected with the HPK 1 expression plasmid by electroporation at $230 \mathrm{~V}$ and $960 \mathrm{mF}$ (Bio-Rad). CAT assays were performed as described previously (Lai et al. 1995).

\section{Immunoprecipitation and Western blot analysis}

Cells were lysed in WCE lysis buffer containing $20 \mathrm{~mm}$ HEPES (pH 7.4), 2 mM EGTA, $50 \mathrm{~mm} \beta$-glycerophosphate, $1 \%$ Triton $\mathrm{X}-100,10 \%$ glycerol, $1 \mathrm{~mm}$ DTT, $2 \mu \mathrm{g} / \mathrm{ml}$ of leupeptine, $5 \mu \mathrm{g} /$ $\mathrm{ml}$ of aprotinin, $1 \mathrm{~mm}$ Pefabloc (Boehringer Mannheim) or PMSF, and $1 \mathrm{~mm}$ sodium orthovanadate. Soluble lysates were prepared by centrifugation at $10,000 \times \mathrm{g}$ for $30 \mathrm{~min}$ at $4^{\circ} \mathrm{C}$. The lysates were precleared using Pansorbin cells (Calbiochem) and then incubated with anti-HPKl or anti-MEKK antibody. After 1 $\mathrm{hr}$ of incubation, immunocomplexes were recovered with the aid of Gamma-Bind Sepharose beads (Pharmacia) and then washed four times with lysis buffer. Subsequently, immunoprecipitates were analyzed by Western blotting after SDS-PAGE (10\%), electroblotted onto PVDF membranes (Novex), and finally probed with the corresponding rabbit antiserum or mouse monoclonal antibody. Immunocomplexes were visualized by enhanced chemiluminescence (ECL) detection (Amersham) using goat anti-rabbit or anti-mouse anti-serum conjugated with horseradish peroxidase as a secondary antibody (PIERCE).

\section{Immunocomplex kinase assays}

Immunocomplex kinase assays were carried out as described (Kyriakis et al. 1992), with some modifications. Cellular HPK1 or INK 1 were precipitated by incubation with rabbit anti-HPK] or anti-JNK1 antisera and protein A-agarose beads (Bio-Rad) in WCE lysis buffer. The immunoprecipitates were washed twice with WCE lysis buffer, twice with $\mathrm{LiCl}$ buffer $[500 \mathrm{mM} \mathrm{LiCl}, 100$ $\mathrm{mm}$ Tris- $\mathrm{Cl}(\mathrm{pH} 7.6)$, and $0.1 \%$ Triton $\mathrm{X}-100)$, and twice with kinase buffer [20 mM MOPS (pH 7.6), $2 \mathrm{mM}$ EGTA, $10 \mathrm{~mm}$ $\mathrm{MgCl}_{2}, 1 \mathrm{mM}$ DTT, $0.1 \%$ Triton X-100, and $1 \mathrm{mM}$ sodium orthovanadate|. Pellets were then mixed with $5 \mu \mathrm{g}$ of substrate, 20 $\mu \mathrm{Ci}$ of $\left[\gamma^{-32} \mathrm{P}\right] \mathrm{ATP}$, and $15 \mu \mathrm{M}$ of unlabeled ATP in $30 \mu \mathrm{l}$ of kinase buffer. The substrates include MBP, Histone $2 \mathrm{~A}$, casein,
GST-c)un(1-193), GST-c)un(1-79), GST-JNK1, and MEKK1(1301) polyhistidine fusion protein. The kinase reaction was performed at $30^{\circ} \mathrm{C}$ for $30 \mathrm{~min}$ and terminated with an equal volume of Laemini sample buffer, and the products were resolved by SDS-PAGE $(10 \%)$.

\section{In-gel kinase assays}

The assays were performed by using the procedures of Kameshita and Fujisawa (1989) with some modifications. Proteins precipitated by anti-JNK1 antiserum and protein A-agarose beads (Bio-Rad) or Pansorbin cells (Calbiochem) were analyzed by SDS-PAGE $(10 \%)$ copolymerized with $40 \mu \mathrm{g} / \mathrm{ml}$ GST-cJun(1193). After electrophoresis, SDS was removed by incubation in $200 \mathrm{ml}$ of $20 \%$ isopropanol in $50 \mathrm{~mm}$ Tris- $\mathrm{Cl}(\mathrm{pH} 8.0)$ for $1 \mathrm{hr}$, followed by $1 \mathrm{hr}$ in $200 \mathrm{ml}$ of $5 \mathrm{~mm}$ DTT in $50 \mathrm{~mm}$ Tris- $\mathrm{Cl} / \mathrm{pH}$ 8.0 . To denature the proteins, the gel was incubated in an $80 \mathrm{ml}$ solution containing $6 \mathrm{M}$ guanidine hydrochloride, $5 \mathrm{~mm} \mathrm{DTT}, 50$ mM Tris- $\mathrm{Cl}(\mathrm{pH} 8.0)$ for $1 \mathrm{hr}$, twice. The proteins were renatured by incubation in $200 \mathrm{ml}$ of $0.04 \%$ Tween $20,1 \mathrm{~mm}$ DTT, $50 \mathrm{~mm}$ Tris- $\mathrm{Cl}(\mathrm{pH} 8.0)$ at $4^{\circ} \mathrm{C}$ without agitation, during which time the incubation buffer was changed every $3 \mathrm{hr}$ for 16-18 hr. For the kinase reaction, the gel was equilibrated in $15 \mathrm{ml}$ of kinase buffer [20 mM HEPES (pH 7.6), $20 \mathrm{mM} \mathrm{MgCl}_{2}, 20 \mathrm{~mm} \beta$-glycerophosphate, $0.1 \mathrm{~mm}$ sodium orthovanadate, $2 \mathrm{mM}$ DTT, $20 \mathrm{~mm}$ $p$-nitrophenylphosphate] for $30-60 \mathrm{~min}$ at $4^{\circ} \mathrm{C}$. The kinase reaction was carried out in $15 \mathrm{ml}$ of the same buffer containing $150 \mu \mathrm{Ci}$ of $\left[\gamma^{-32} \mathrm{P}\right] \mathrm{ATP}$ and $50 \mathrm{~mm}$ of ATP for $60 \mathrm{~min}$ at $30^{\circ} \mathrm{C}$. The gel was washed extensively with $5 \%$ (wt/vol) trichloroacetic acid plus $1 \%$ sodium pyrophosphate until the washes were free of radioactivity. The gel was dried and subjected to autoradiography.

\section{Phosphoamino acid analysis}

The phosphorylated proteins obtained from the immunocomplex kinase assays were transferred electrophoretically to PVDF membranes. The spots containing phosphoproteins on the membranes were excised according to the bands on theautoradiograms, and then hydrolyzed in $50 \mu \mathrm{l} 6 \mathrm{~N} \mathrm{HCl}$ for $1 \mathrm{hr}$ at $110^{\circ} \mathrm{C}$. The supernatant was lyophilized and dissolved in $6 \mu 1$ pH 1.9 buffer containing cold phosphoamino acids as markers. The phosphoamino acids were resolved electrophoretically in two dimensions using a thin-layer cellulose (TLC) plate with two $\mathrm{pH}$ systems as described (Boyle et al. 1991). The markers were visualized by staining with $0.2 \%$ ninhydrin in acetone and the ${ }^{32}$ p-labeled residues were detected by autoradiography.

\section{Small GTPases-binding assay}

The small GTPase GST-Rac1, GST-Cdc42, GST-Ras, and GST-RhoA fusion proteins were expressed in bacteria and recovered on glutathione-Sepharose $4 \mathrm{~B}$ beads (Pharmacia) according to the manufacturer's instructions. KGla and Raji wholecell lysates $(20 \mathrm{mg}$ each) were passed through a glutathioneSepharose column preloaded with each of the GST-GTPase fusion proteins and $1 \mu \mathrm{M}$ GTP- $\gamma$-S (Sigma). The column was washed with $40 \mathrm{ml}$ (at least 20 bed volumes) of PBS, and the bound proteins were eluted with glutathione elution buffer. Proteins were resolved by electrophoresis in an $8 \%$ SDS-PAGE, transferred to a PVDF membrane, and probed with either an anti-PAK1 antibody or an anti-HPK1 antibody. Immunocomplexes were visualized by the ECL detection system as described above. 


\section{Acknowledgments}

We are grateful to J. Bruder, R.A. Cerione, R.J. Davis, J.S. Gutkind, G. Johnson, M. Karin, A. Polverino, D. Templeton, and L.I. Zon for generous gifts of plasmids; L. Antonio for DNA sequencing; W. Boyle for help with phosphoamino acid analysis; J.-H. Shieh, I. McNiece, and G. Elliott for purified human progenitor cells; A. Brown and S.L. Chien for technical assistance; C. Chang and M. Lowe for secretarial and editorial assistance; R. Bosselman and L. Souza for support. We thank F. Kiefer and N.N. Iscove for sharing the unpublished information and reagents of the murine HPKI homolog. C.F. Meyer was supported by a National Institutes of Health (NIH) training grant in AIDS research (T32-AI07483) and is a NIH predoctoral trainee in immunology (T32-AI07495). T.-H. Tan is a Scholar of the Leukemia Society of America. This work was supported by Amgen (to M.C.-T.H.) and the NIH grants RO1-GM49875 and ROlAI38649 (to T.-H.T.).

The publication costs of this article were defrayed in part by payment of page charges. This article must therefore be hereby marked "advertisement" in accordance with 18 USC section 1734 solely to indicate this fact.

\section{References}

Angel, P., M. Imagawa, R. Chiu, B. Stein, R.J. Imbra, H.J. Rahmsdorf, C. Jonat, P. Herrich, and M. Karin. 1987. Phorbol ester-inducible genes contain a common cis element recognized by a TPA-modulated trans-acting factor. Cell 49: 729739.

Angel, P., K. Hattori, T. Smeal, and M. Karin. 1988. The c-jun proto-oncogene is positively autoregulated by its product, Jun/AP-1. Cell 55: 875-885.

Bagrodia, S., B. Derijard, R.J. Davis, and R.A. Cerione. 1995a. Cdc42 and PAK-mediated signaling leads to Jun kinase and p38 mitogen-activated protein kinase activation. $/$. Biol. Chem. 270: 27995-27998.

Bagrodia, S., S.J. Taylor, C.L. Creasy, J. Chernoff, and R.A. Cerione. $1995 \mathrm{~b}$. Identification of a mouse $\mathrm{p} 21^{\mathrm{Cdc} 42 / \mathrm{Rac}}$ activated kinase. J. Biol. Chem. 270: 22731-22737.

Blank, J.L., P. Gerwins, E.M. Elliott, S. Sather, and G.L. Johnson. 1996. Molecular cloning of mitogen-activated protein/ERK kinase kinases (MEKK) 2 and 3. I. Biol. Chem. 271: 53615368.

Boyle, W.J., P. van der Geer, and T. Hunter. 1991. Phosphopeptide mapping and phosphoamino acid analysis by two-dimensional separation on thin-layer cellulose plates. Methods Enzymol. 201: 110-149.

Brady, G., F. Billia, J. Knox, T. Hoang, I.R. Kirsch, E.B. Voura, R.G. Hawley, R. Cumming, M. Buchwald, K. Siminovitch, N. Miyamoto, G. Boehmelt, and N.N. Iscove. 1995. Analysis of gene-expression in a complex differentiation hierarchy by global amplification of cDNA from single cells. Curr. Biol. 5: 909-922.

Burbelo, P.D., D. Drechsel, and A. Hall. 1995. A conserved binding motif defines numerous candidate target proteins for both Cdc42 and Rac GTPases. I. Biol. Chem. 270: 2907129074.

Chen, Y.-R., C.F. Meyer, and T.-H. Tan. 1996. Persistent activation of c-Jun $\mathrm{N}$-terminal kinase 1 (JNK1) in gamma radiation-induced apoptosis. J. Biol. Chem. 271: 631-634.

Cobb, M.H. and E.J. Goldsmith. 1995. How MAP kinase are regulated. I. Biol. Chem. 270: 14843-14846.

Cohen, G.B., R. Ren, and D. Baltimore. 1995. Modular binding domains in signal transduction proteins. Cell 80: 237-248.

Coso, O.A., M. Chiariello, J.-C. Yu, H. Teramoto, P. Crespo, N.
Xu, T. Miki, and J.S. Gutkind. 1995. The small GTP-binding proteins Racl and Cdc42 regulate the activity of the JNK/ SAPK signaling pathway. Cell 81: 1137-1146.

Davis, R.J. 1993. The mitogen-activated protein kinase signal transduction pathway. I. Biol. Chem. 268: 14553-14556.

- 1994. MAPKs: New INK expands the group. Trends Biochem. Sci. 19: 470-473.

Derijard, B., M. Hibi, I.-H. Wu, T. Barret, B. Su, T. Deng, M. Karin, and R.J. Davis. 1994. JNK1: A protein kinase stimulated by UV light and Ha-Ras that binds and phosphorylates the c-Jun activation domain. Cell 76: 1025-1037.

Derijard, B., J. Raingeaud, T. Barrett, I-H. Wu, J. Han, R.J. Ulevitch, and R.J. Davis. 1995. Independent human MAP kinase signal transduction pathways defined by MEK and MKK isoforms. Science 267: 682-685.

Feng, S., J.K. Chen, H. Yu, J.A. Simon, and S.L. Schreiber. 1994. Two binding orientations for peptides to the Src SH3 domain: Development of a general model for SH3-ligand interactions. Science 266: 1241-1247.

Finlay, C.A., P.W. Hinds, T.-H. Tan, D. Eliyahu, M. Oren, and A.J. Levine. 1988. Activating mutations for transformation by p 53 produce a gene product that forms an hsc 70-p53 complex with an altered half-life. Mol. Cell. Biol. 8: 531539.

Friesen, H., R. Lunz, S. Doyle, and J. Segall. 1994. Mutation of the SPS1-encoded protein kinase of Saccharomyces cerevisiae leads to defects in transcription and morphology during spore formation. Genes \& Dev. 8: 2162-2175.

Gupta, S., T. Battett, A.J. Whitmarsh, J. Cavanagh, H.K. Sluss, B. Derijard, and R.J. Davis. 1996. Selective interaction of JNK protein kinase isoforms with transcription factors. $E M B O F$. 15: $2760-2770$.

Han, J., J.-D. Lee, L. Bibbs, and R.J. Ulevitch. 1994. A MAP kinase targeted by endotoxins and hyperosmolarity in mammalian cells. Science 265: 808-811.

Hanks, S.K. 1991. Eukaryotic protein kinases. Curr. Opin. Struct. Biol. 1: 369-383.

Hanks, S.K. and A.M. Quinn. 1991. Protein kinase catalytic domain sequence database: Identification of conserved features of primary structure and classification of family members. Methods Enzymol. 200: 38-62.

Herskowitz, I. 1995. MAP kinase pathways in yeast: For mating and more. Cell 80: 187-197.

Hirai, S.-i., M. Izawa, S-i. Osada, G. Spyrou, and S. Ohno. 1996. Activation of the JNK pathway by distantly related protein kinases, MEKK and MUK. Oncogene 12: 641-650.

Huang, S. and L.W. Terstappen. 1994. Lymphoid and myeloid differentiation of single human $\mathrm{CD} 34^{+}, \mathrm{HLA}^{-\mathrm{DR}}{ }^{+}, \mathrm{CD}^{-} 8^{-}$ hematopoietic stem cells. Blood 83: 1515-1526.

Hunter, T. 1995. Protein kinases and phosphatases: The yin and yang of protein phosphorylation and signaling. Cell 80: 225236.

Jiang, Y., C. Chen, Z. Li, W. Guo, J.A. Gegner, S. Lin, and J. Han. 1996. Characterization of the structure and function of a new mitogen-activated protein kinase $(\mathrm{p} 38 \beta)$. I. Biol. Chem. 271: 17920-17926.

Kameshita, I. and H. Fujisawa. 1989. A sensitive method for detection of calmodulin-dependent protein kinase II activity in sodium dedecyl sulfate-polyacrylamide. Anal. Biochem. 183: 139-143.

Karin, M. 1995. The regulation of AP-1 activity by mitogenactivated protein kinases. J. Biol. Chem. 270: 16483-16486.

Katz, P., G. Whalen, and J.H. Kehrl. 1994. Differential expression of a novel protein kinase in human B lymphocytes. Preferential localization in the germinal center. I. Biol. Chem. 269: 16802-16809. 
Kyriakis, J.M., H. App, X.F. Zhang, P. Banerjee, D.L. Brautigan, U.R. Rapp, and J. Avruch. 1992. Raf-1 activates MAP kinasekinase. Nature 358: 417-421.

Kyriakis, J., P. Baneriee, E. Nikolakaki, T. Dai, E. Rubie, M. Ahmad, J. Avruch, and J. Woodgett. 1994. The stress-activated protein kinase subfamily of c-Jun kinases. Nature 369: $156-160$

Lai, J.-H., G. Horvath, J. Subleski, J. Bruder, P. Ghosh, and T.-H. Tan. 1995. RelA is a potent transcriptional activator of the CD28 response element within the interleukin 2 promoter. Mol. Cell. Biol. 15: 4260-4271.

Lange-Carter, C.A., C.M. Pleiman, A.M. Gardner, K.J. Blumer, and G.L. Johnson. 1993. A divergence in the MAP kinase regulatory network defined by MEK kinase and Raf. Science 260: $315-319$.

Leberer, E., D. Dignard, D. Harcus, D.Y. Thomas, and M. Whiteway. 1992. The protein kinase homologue Ste20p is required to link the yeast pheromone response G-protein $\beta \gamma$ subunits to downstream signalling components. EMBO $/$. 11: 48154824.

Manser, E., T. Leung, H. Salihuddin, Z.-s. Zhao, and L. Lim. 1994. A brain serin/threonine protein kinase activated by Cdc42 and Racl. Nature 367: 40-46.

Marcus, S., A. Polverino, E. Chang, D. Robbins, M.H. Cobb, and M.H. Wigler. 1995. Shk1, a homolog of the Saccharomyces cerevisiae Ste 20 and mammalian p65PAK protein kinases, is a component of a Ras/Cdc42 signaling module in the fission yeast Schizosaccharomyces pombe. Proc. Natl. Acad. Sci. 92: 6180-6184.

Marshall, C.J. 1995. Specificity of receptor tyrosine kinase signaling: transient versus sustained extracellular signal-regulated kinase activation. Cell 80: 179-185.

Martin, G.A., G. Bollag, F. McCormick, and A. Abo. 1995. A novel serine kinase activated by racl/CDC42HS-dependent autophosphorylation is related to PAK65 and STE20. EMBO J. 14: 1970-1978.

Meyer, C.F., X. Wang, C. Chang, D.L. Templeton, and T.-H. Tan. 1996. Interaction between c-Rel and the mitogen-activated protein kinase kinase kinase 1 signaling cascade in mediating B enhancer activation. J. Biol. Chem. 271: 89718976.

Minden, A., A. Lin, M. McMahon, C. Lange-Carter, B. Derijard, R.J. Davis, G.L. Johnson, and M. Karin. 1994. Differential activation of ERK and JNK mitogen-activated protein kinases by Raf-1 and MEKK. Science 266: 1719-1723.

Minden, A., A. Lin, F.-X. Claret, A. Abo, and M. Karin. 1995. Selective activation of the JNK signaling cascade and c-Jun transcriptional activity by the small GTPases Rac and Cdc42Hs. Cell 81: 1147-1257.

Raingeaud, J., S. Gupta, J.S. Rogers, M. Dickens, J. Han, R.J. Ulevitch, and R.J. Davis. 1995. Pro-inflammatory cytokines and environmental stress cause p38 mitogen-activated protein kinase activation by dual phosphorylation on tyrosine and threonine. J. Biol. Chem. 270: 7420-7426.

Ramer, S.W. and R.W. Davis. 1993. A dominant truncation allele identifies a gene, STE20, that encodes a putative kinase necessary for mating in Saccharomyces cerevisiae. Proc. Natl. Acad. Sci. 90: 452-456.

Rana, A., K. Gallo, P. Godowski, S. Hirai, S. Ohno, L. Zon, J.M. Kyriakis, and J. Avruch. 1996. The mixed lineage kinase SPRK phosphorylates and activates the stress-activated protein kinase activator, SEK-1. J. Biol. Chem. 271: 1902519028.

Russell, M., C.A. Lange-Carter, and G.L. Johnson. 1995. Direct interaction between Ras and the kinase domain of mitogen- activated protein kinase kinase kinase (MEKK1). I. Biol. Chem. 270: 11757-11760.

Sakata, N., H.R. Patel, N. Terada, A. Aruffo, G.L. Johnson, and E.W. Gelfand. 1995. Selective activation of c-Jun kinase mitogen-activated protein kinase by CD40 on human B cells. $I$. Biol. Chem. 270: 30823-30828.

Saleem, A., R. Dattaa, Z.-M. Yuan, S. Kharbanda, and D. Kufe. 1995. Involvement of stress-activated protein kinase in the cellular response to $1-\beta-D$-arabinofuranosylcytosine and other DNA-damaging agents. Cell Growth Diff. 6: 16511658.

Salmeron, A., T.B. Ahmad, G.W. Carlile, D. Pappin, R.P. Narsimhan, and S.C. Ley. 1996. Activation of MEK-1 and SEK-1 by $\mathrm{Tpl}-2$ proto-oncoprotein, a novel MAP kinase kinase. EMBO I. 15: 817-826.

Sambrook, J., E.F. Fritsch, and T. Maniatis. 1989. Molecular cloning: A laboratory manual, 2nd ed. Cold Spring Harbor Laboratory Press, Cold Spring Harbor, NY.

Sanchez, I., R.T. Hughes, B.J. Mayer, K. Yee, J.R. Woodgett, J. Avruch, J.M. Kyriakis, and L.I. Zon. 1994. Role of SAPK/ ERK kinase-1 in the stress-activated pathway regulating transcription factor c-Jun. Nature 372: 794-798.

$\mathrm{Su}$, B., E. Jacinto, T. Kallunki, M. Karin, and Y. Ben-Neriah. 1994. JNK is involved in signal integration during costimulation of $\mathrm{T}$ lymphocytes. Cell 77: 727-736.

Verheij, M., R. Bose, X.H. Lin, B. Yao, W.D. Jarvis, S. Grant, M.J. Birrer, E. Szabo, L.I. Zon, J.M. Kyriakis, A. Haimovitz-Friedman, Z. Fuks, and R.N. Kolesnick. 1996. Requirement for ceramide-initiated SAPK/JNK signalling in stress-induced apoptosis. Nature 380: 75-79.

Westwick, J.K., A.E. Bielawska, G. Dbaibo, Y.A. Hannun, and D.A. Brenner. 1995. Ceramide activates the stress-activated protein kinases. I. Biol. Chem. 270: 22689-22692.

Xia, Z., M. Dickens, J. Raingeaud, R.J. Davis, and M.E. Greenberg. 1995. Opposing effects of ERK and JNK-p38 MAP kinases on apoptosis. Science 270: 1326-1331.

$\mathrm{Xu}$, S., D.J. Robbins, L.B. Christerson, J.M. English, C.A. Vanderbilt, and M.H. Cobb. 1996. Cloning of rat MEK kinase 1 cDNA reveals an endogenous membrane-associated 195kDa protein with a large regulatory domain. Proc. Natl. Acad. Sci. 93: 5291-5295.

Yamaguchi, K., K. Shirakabe, H. Shibuya, K. Irie, I. Oishi, N. Ueno, T. Taniguchi, E. Nishida, and K. Matsumoto. 1995. Identification of a member of the MAPKKK family as a potential mediator of TGF- $\beta$ signal transduction. Science 270: 2008-2011.

Yan, M., T. Dai, J.C. Deak, J.M. Kyriakis, L.I. Zon, J.R. Woodgett, and D.J. Templeton. 1994. Activation of stressactivated protein kinase by MEKKl phosphorylation of its activator SEK1. Nature 372: 798-800.

Yoshinaga, S. K., P.A. Boulanger, and A.J. Berk. 1987. Resolution of human transcription factor TFIIIC into two functional components. Proc. Natl. Acad. Sci. 84: 3585-3589.

Zhang, S., J. Han, M.A. Sells, J. Chernoff, U.G. Knaus, R.J. U1evitch, and G.M. Bokoch. 1995. Rho family GTPases regulate $\mathrm{p} 38$ mitogen-activated protein kinase through the downstream mediator Pakl. J. Biol. Chem. 270: 23934-23936. 


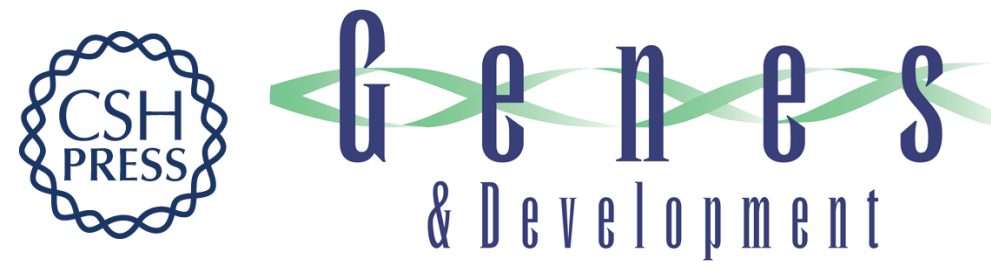

\section{Human HPK1, a novel human hematopoietic progenitor kinase that activates the JNK/SAPK kinase cascade.}

M C Hu, W R Qiu, X Wang, et al.

Genes Dev. 1996, 10:

Access the most recent version at doi:10.1101/gad.10.18.2251

References This article cites 60 articles, 33 of which can be accessed free at:

http://genesdev.cshlp.org/content/10/18/2251.full.html\#ref-list-1

License

Email Alerting

Service

Receive free email alerts when new articles cite this article - sign up in the box at the top right corner of the article or click here.

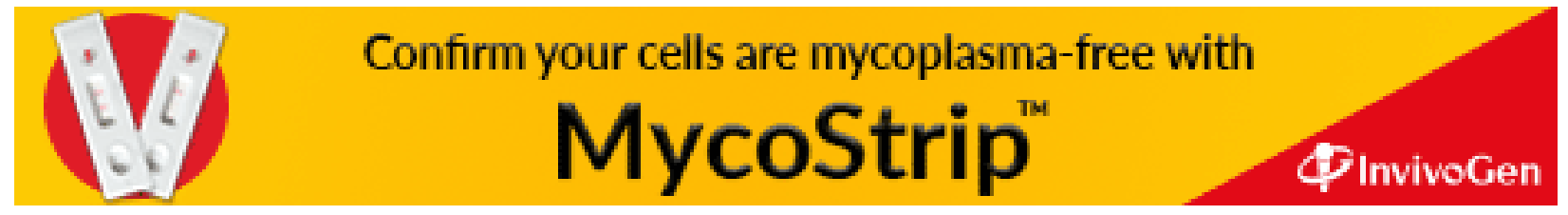

